\title{
Hazard Analysis of Landslides Triggered by Typhoon Chata'an on July 2, 2002, in Chuuk State, Federated States of Micronesia
}

By Edwin L. Harp, Mark E. Reid, and John A. Michael

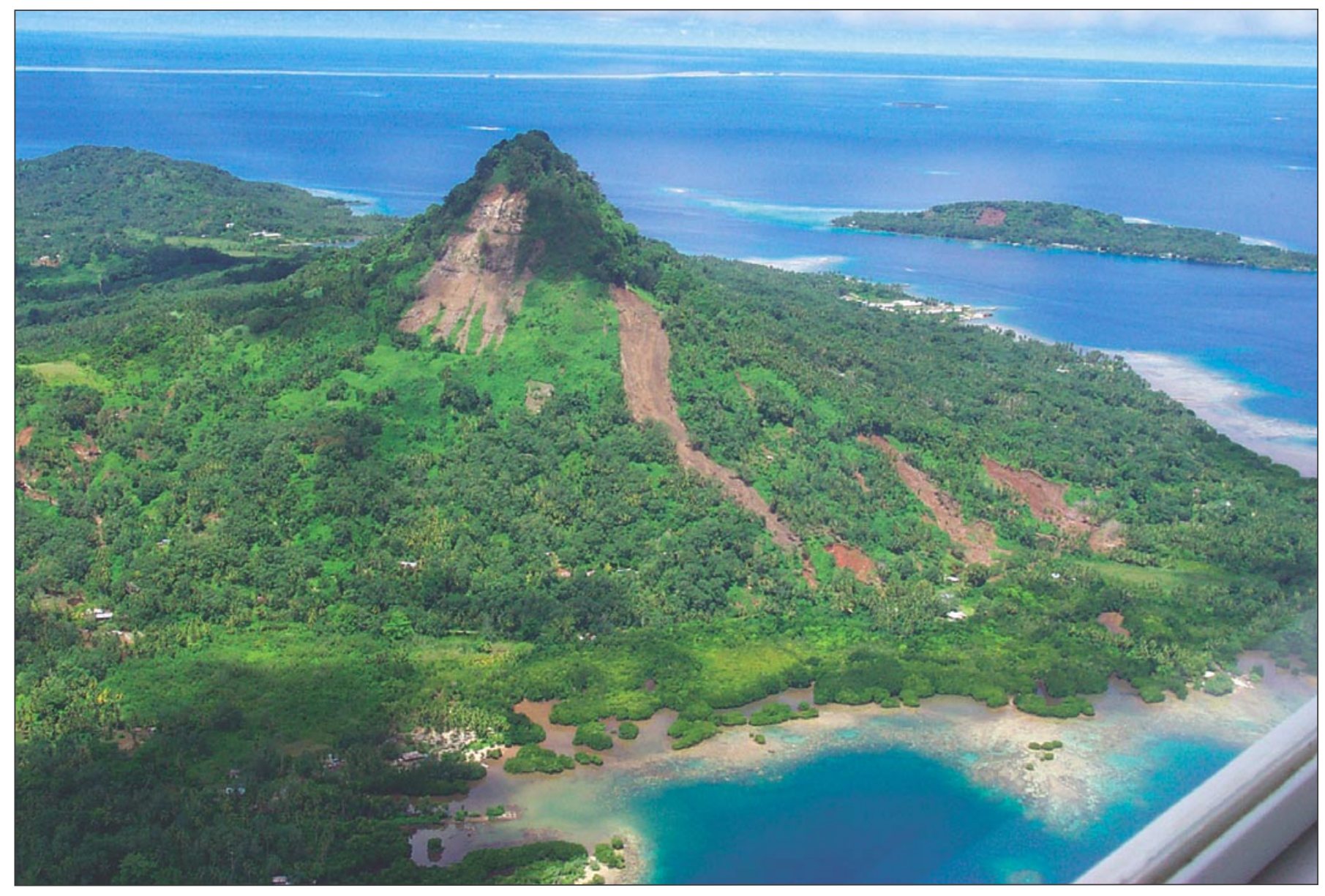

U.S. Geological Survey Open-File Report 2004-1348 


\section{Contents}

Abstract

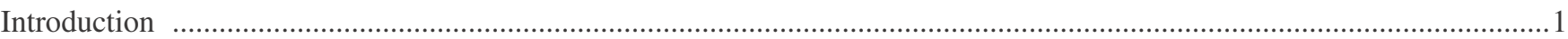

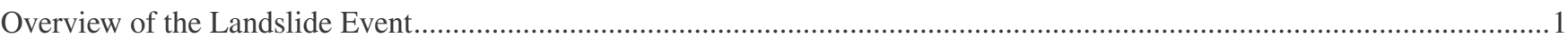

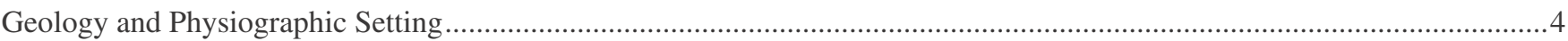

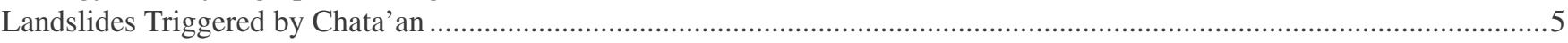

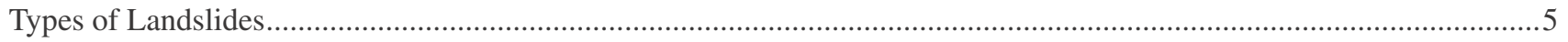

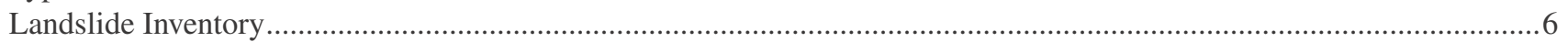

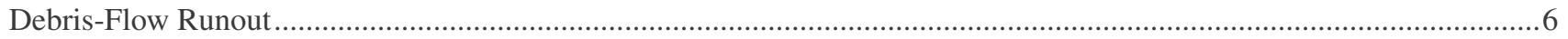

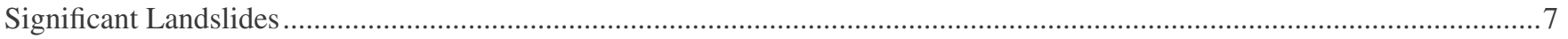

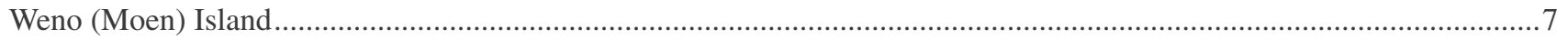

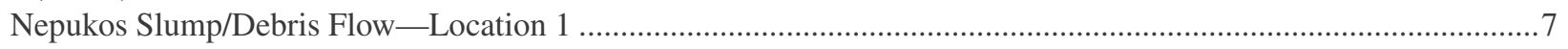

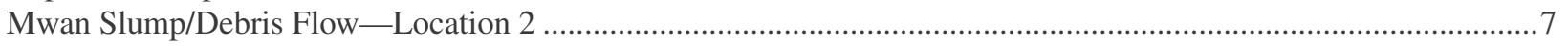

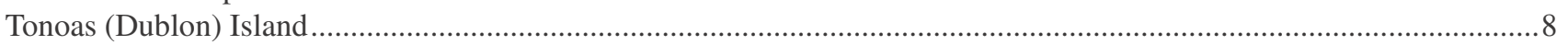

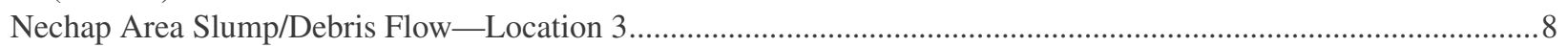

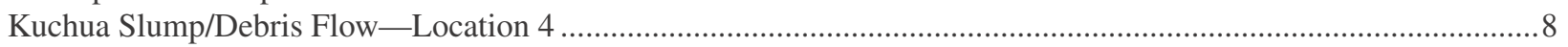

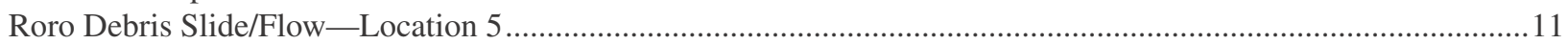

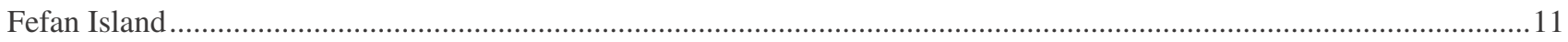

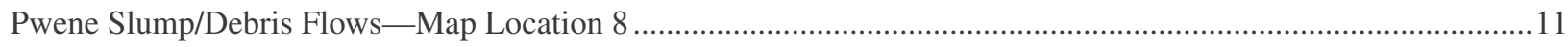

Sapore Slump/Debris Flow and Incipient Landslide_Map Location 10 ..........................................................11

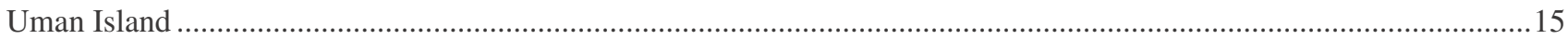

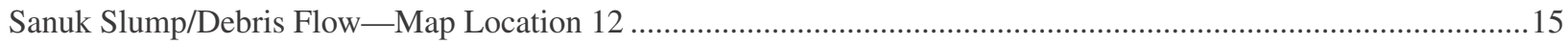

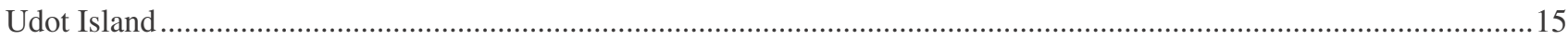

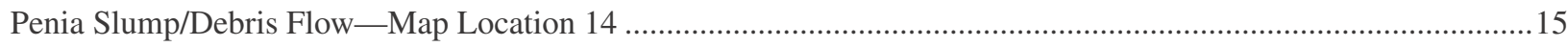

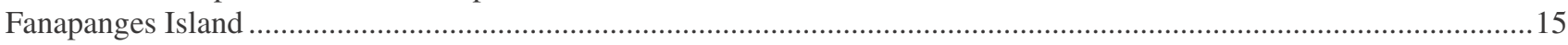

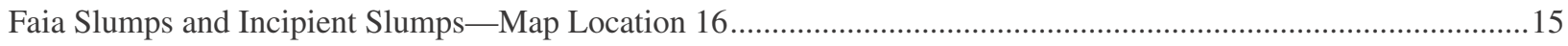

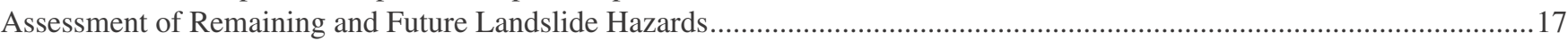

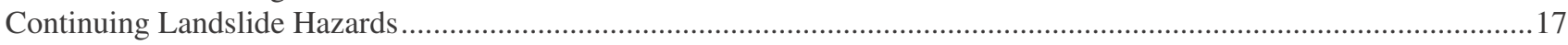

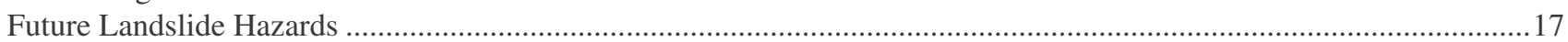

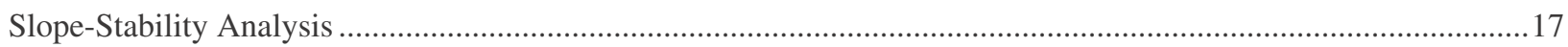

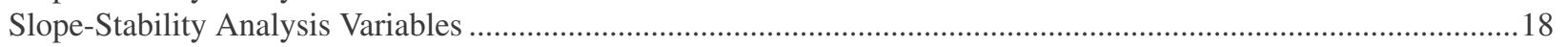

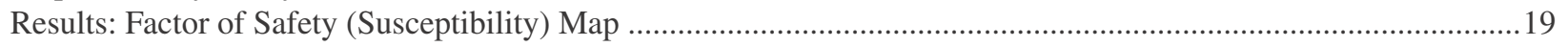

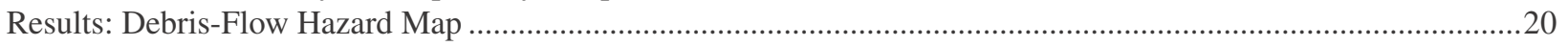

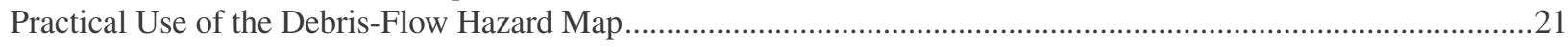

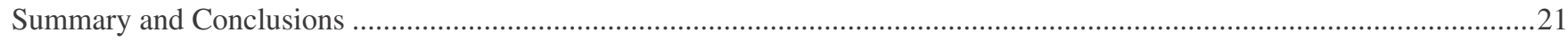

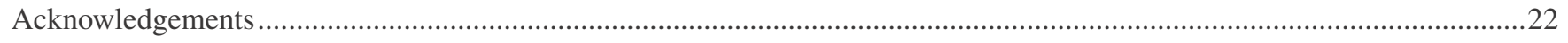

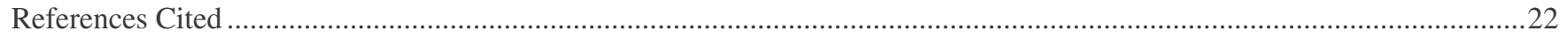

Any use of trade, firm, or product names is for descriptive purposes only and does not imply endorsement by the U.S. Government.

Suggested citation: Harp, E.L., Reid, M.E., and Michael, J.A., 2004, Hazard analysis of landslides triggered by Typhoon Chata' an on July 2, 2002, in Chuuk State, Federated States of Micronesia (ver. 1.1, July 2021): U.S. Geological Survey Open-File Report 2004-1348, 22 p., 2 pls., scale 1:25,000, https://doi.org/10.3133/ofr20041348.

Cover Photo: Oblique aerial view of debris flows on the island of Tonoas in Chuuk State, Federated States of Micronesia triggered by Typhoon Chata'an. 


\section{ABSTRACT}

More than 250 landslides were triggered across the eastern volcanic islands of Chuuk State in the Federated States of Micronesia by torrential rainfall from tropical storm Chata'an on July 2, 2002. Landslides triggered during nearly 20 inches of rainfall in less than 24 hours caused 43 fatalities and the destruction or damage of 231 structures, including homes, schools, community centers, and medical dispensaries. Landslides also buried roads, crops, and water supplies. The landslides ranged in volume from a few cubic meters to more than 1 million cubic meters. Most of the failures began as slumps and transformed into debris flows, some of which traveled several hundred meters across coastal flatlands into populated areas. A landslide-inventory map produced after the storm shows that the island of Tonoas had the largest area affected by landslides, although the islands of Weno, Fefan, Etten, Uman, Siis, Udot, Eot, and Fanapanges also had significant landslides. Based on observations since the storm, we estimate the continuing hazard from landslides triggered by Chata'an to be relatively low. However, tropical storms and typhoons similar to Chata'an frequently develop in Micronesia and are likely to affect the islands of Chuuk in the future. To assess the landslide hazard from future tropical storms, we produced a hazard map that identifies landslide-source areas of high, moderate, and low hazard. This map can be used to identify relatively safe areas for relocating structures or establishing areas where people could gather for shelter in relative safety during future typhoons or tropical storms similar to Chata'an.

\section{INTRODUCTION}

On July 2, 2002, heavy rains from tropical storm Chata'an (subsequently Super Typhoon Chata'an) triggered several hundred landslides across various islands of Chuuk State in the Federated States of Micronesia (figs. 1 and 2), resulting in 43 fatalities and the destruction or damage of 231 structures (FEMA Internal Report). Landslide specialists from the U.S. Geological Survey (USGS) were requested to perform a reconnaissance of the landslides and to evaluate the continuing landslide hazards to residents and property on the affected islands of Chuuk State. This work was conducted under the Federal Emergency Management Agency (FEMA) mission assignment subtask 1427-DR-FM-COE-POD-05 with the U.S. Army Corps of Engineers (USACE).

Between July 27 and August 7, 2002, USGS landslide specialists and USACE geotechnical engineers conducted a field reconnaissance of the Chuuk islands affected by landslides triggered by tropical storm Chata'an. USGS scientists (Harp and Reid) obtained a broad overview of the landslide distribution by means of an aerial overflight and performed detailed field investigations of selected highimpact landslides to assess failure processes, to analyze the distribution of failures, and to evaluate the remaining hazard to people and property in future rainfall events. We provided preliminary information about continuing landslide hazards in Chuuk State to FEMA and the USACE in August 2002. Following this field reconnaissance, we prepared a detailed inventory map of the landslides triggered by Chata'an. Using Geographical Information System (GIS) technology, we then applied a slope-stability analysis to the islands affected by landslides from Chata'an and created a hazard map portraying the likely locations of future debris flows. In September 2003, we returned to Chuuk State to present these hazard maps to local officials and to examine the status of the previous year's landslides.

This report first presents an overview of the landslide event, the types and distribution of landsliding triggered by Chata'an, and individual descriptions of some of the significant landslides. The report then discusses continuing hazards from landslides for the islands affected by Chata'an. To address landslide hazard, the report presents a landslide (debris-flow) hazard map and discusses possible uses of this map.

\section{OVERVIEW OF THE LANDSLIDE EVENT}

Intense rainfall from tropical storm Chata'an pounded the islands of Chuuk State on July 1 and 2, 2002. This deluge triggered at least 269 landslides on steeper slopes of the islands of Weno (Moen), Tonoas (Dublon), Fefan, Etten, Uman, Siis, Udot, Eot, and Fanapanges (Falabeguets), all located within Chuuk (Truk) Lagoon (table 1 and fig. 2). During the storm, 43 people were killed, and 231 structures were destroyed by landslides (FEMA Internal Report). Landslides affected the greatest area on Tonoas. Aerial reconnaissance identified only a few, relatively small recent landslides on the island of Tol and nearby small islands.

According to local residents, most of the landslides occurred between 7 a.m. and 2 p.m. on July 2. At the airport on the island of Weno, 19.74 inches of rain fell on July 2, with several rain bursts having hourly intensities greater than 3 inches per hour (fig. 3). Although the timing and amounts of rainfall likely varied between islands, many of the landslides appear to have been triggered during or immediately following intense rain bursts (fig. 3). Residents experienced prolonged thunder and lightening during the storms, often during the time when landsliding occurred. Hundreds of people evacuated their homes in fear of future landsliding, and many remained evacuated more than a month later.

The landslides triggered by Chata'an range in volume from a few cubic meters to more than 1 million $\mathrm{m}^{3}$ and occurred in deeply-weathered volcanic rocks. Most of the landslides that caused fatalities and property damage were slumps (coherent failure masses whose downslope movement commonly has a rotational component) that transformed into debris flows. After starting to move downslope, many of the landslides transformed into debris flows, slurry-like mixtures of water, clay, sand, silt, and boulders. The larger and particularly destructive debris flows appeared to be aided in this transformation by water impounded by the slump, 

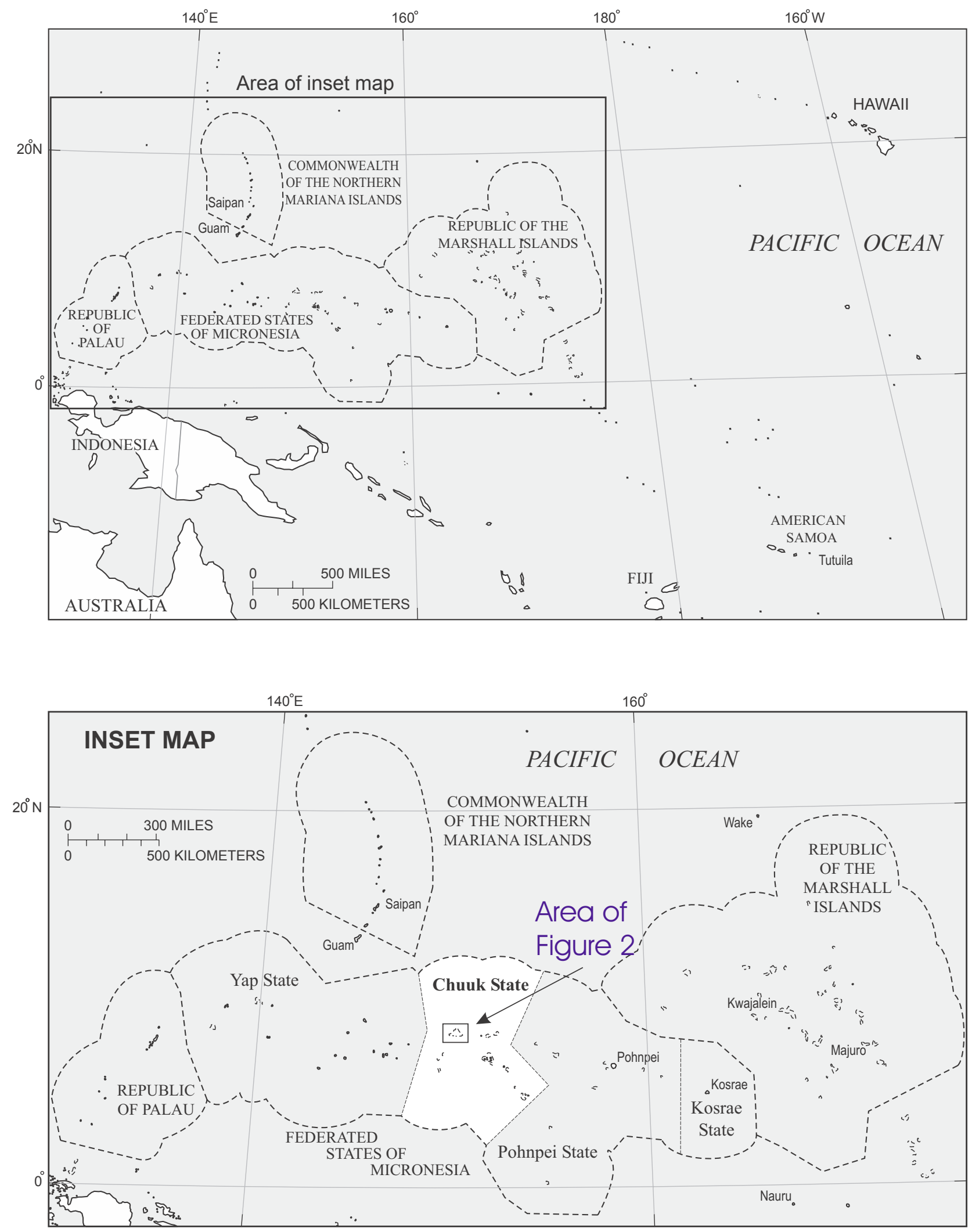

Figure 1. Map of the western Pacific Ocean showing locations of the Federated States of Micronesia and of Chuuk State (after Hamlin and Takasaki, 1984-85). 


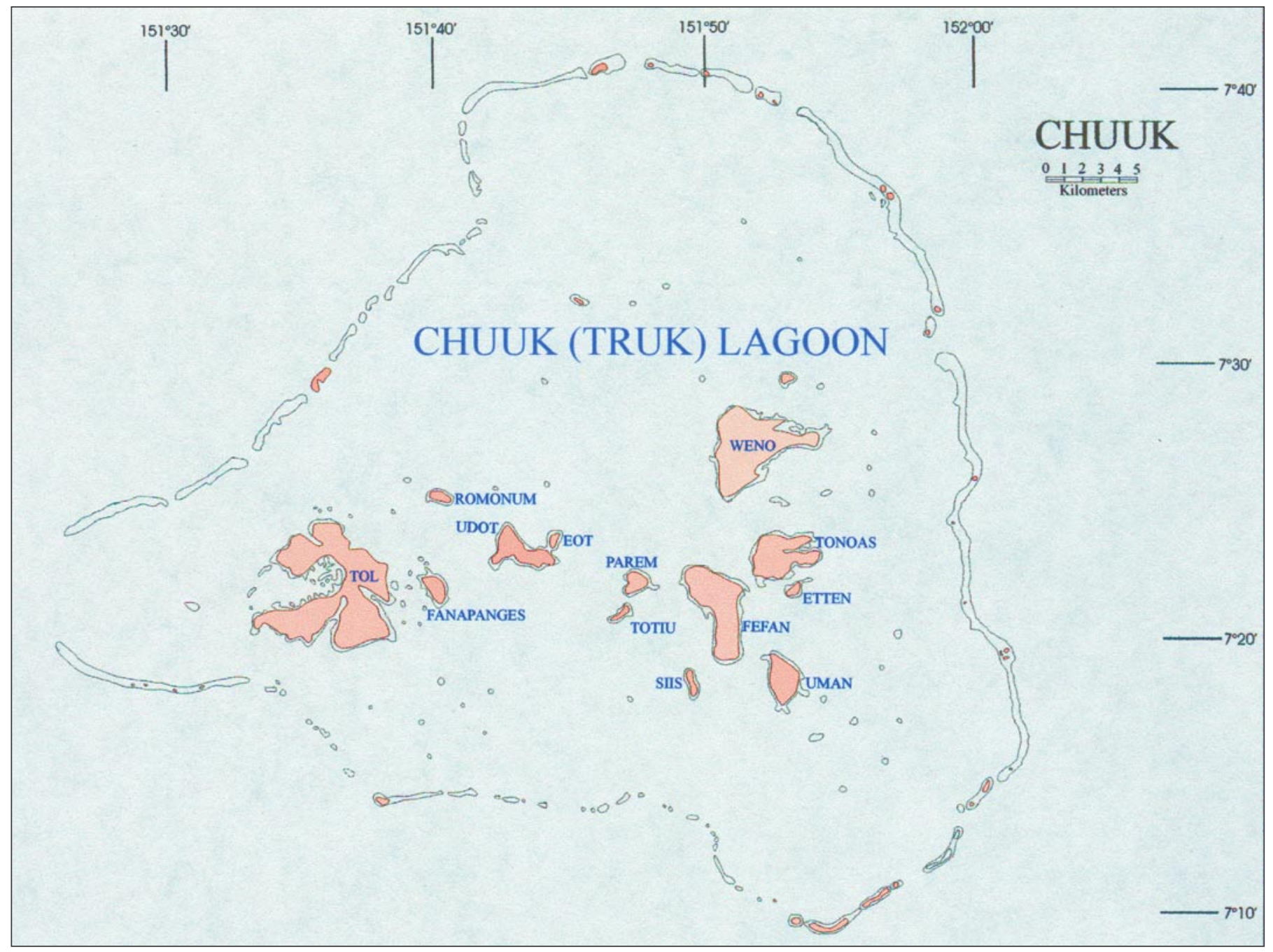

Figure 2. Map of Chuuk islands within Chuuk (Truk) Lagoon (after Hamlin and Takasaki, 1984-85).

Table 1. Amount of landsliding on the islands of Chuuk State, Federated States of Micronesia, trigg ered by tropical storm Chata'an $\underline{\text { Number of slides }} \quad \underline{\text { Area of island }\left(\mathrm{m}^{2}\right)} \quad \underline{\text { Area of slides }\left(\mathrm{m}^{2}\right)} \quad \begin{gathered}\begin{array}{c}\text { Percent of island } \\ \text { affected by landslides }\end{array} \\ \begin{array}{c}\text { Percent of coastal lowlands } \\ \text { affected by landslides }\end{array}\end{gathered}$

$\begin{array}{lccccc}\text { Weno } & 64 & 18,735,300 & 327,000 & 1.7 & 7.7 \\ \text { Tonoas } & 57 & 8,674,700 & 663,900 & 3.9 & 5.1 \\ \text { Fefan } & 96 & 12,051,400 & 468,900 & 6.3 & 2.4 \\ \text { Uman } & 23 & 3,985,300 & 252,400 & 3.3 & 6.7 \\ \text { Etten } & 5 & 525,300 & 17,500 & 3.2 & 1.6 \\ \text { Udot } & 20 & 4,546,400 & 145,700 & 0.6 & 0.9 \\ \text { Eot } & 1 & 363,200 & 2,300 & 1.5 & 1.6 \\ \text { Fanapanges } & 3 & 1,656,200 & 24,200 & & 2.8\end{array}$




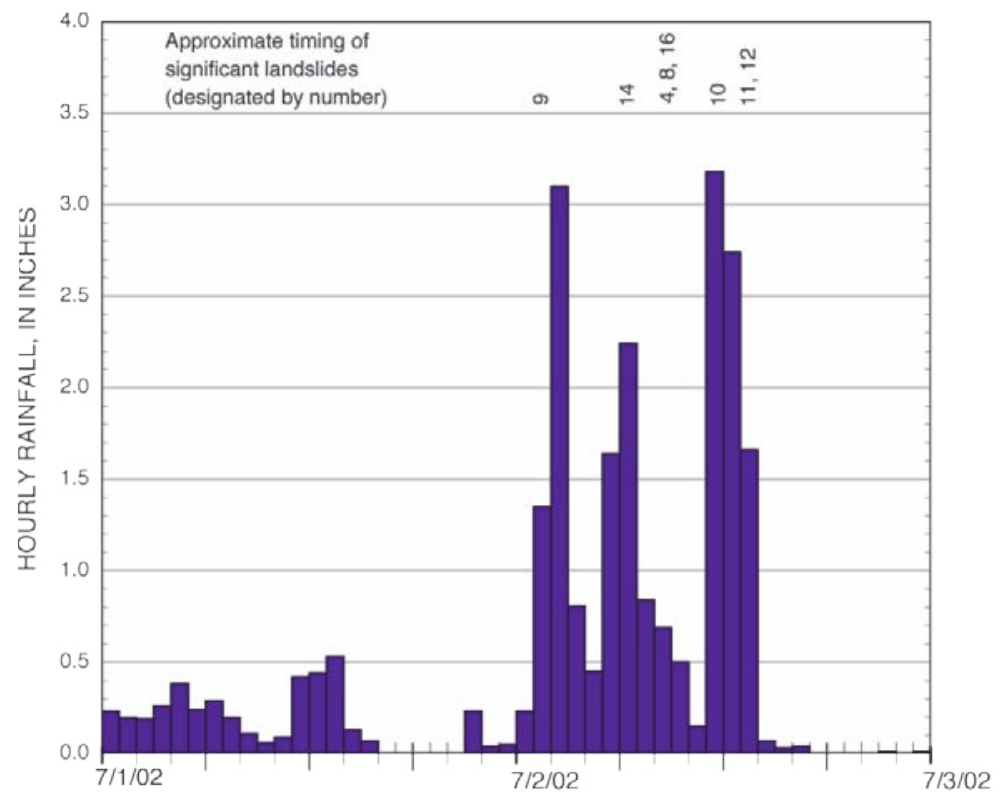

Figure 3. Bar graph of hourly rainfall from tropical storm Chata'an at Weno airport (WSO) station. Time of occurrence of significant landslides obtained from local residents. Table 2 contains more information about the significant landslides (by number). either directly behind the rotated slump mass or upstream of a temporary landslide dam. Debris flows can travel rapidly (as fast as $50 \mathrm{~km} / \mathrm{hr}$ ) and can flow long distances over relatively gentle slopes. Most of the debris flows formed during Chata'an raced down steeper slopes, coming to rest only after traveling across flat coastal lowlands. The largest debris flow, which occurred on Fefan, traveled more than 700 m, whereas smaller flows typically traveled about $100 \mathrm{~m}$ or less across the coastal lowlands. These debris flows buried people and crushed many homes and other structures in their paths (see table 2).

In addition to these slump/debris flows, many incipient landslides currently exist on the islands. These are areas that began to slide during the storm but did not fully fail. They are characterized by fresh tensional cracking at their upslope margins; typically cracks are open or the downslope side has dropped. Lateral and toe areas of these incipient slides may not be well defined. These features range in length from a few meters to more than $300 \mathrm{~m}$; many are slightly arcuate in plan view and suggest rotational movement.

Landslides triggered by strong tropical storms are a recurring phenomenon in the Chuuk islands. Geomorphic evidence of previous landslides is present on many steeper slopes in the Chuuk islands. In 1976, Typhoon Pamela initiated a landslide that killed people on the island of Weno, and in February of 2002, a rainstorm triggered a large landslide visible on the eastern slope of the island of Tol (Johnson Elimo, personal commun., 2002). In recent years, landslides and debris flows triggered by tropical storms have occurred on other volcanic islands with steep slopes throughout the Pacific Ocean, such as Tonga and Vanuatu. Reports document extensive storm-related landslide activity on Pohnpei, Federated States of Micronesia (Harp and Savage, 1997) and on the island of Oahu, Hawaii (Ellen and others,
1991, Peterson and others, 1993). The greatest loss of life from a landslide in North American history was caused by a landslide within the Mameyes district in the city of Ponce, Puerto Rico triggered by Tropical Storm Isabel in October 1985 ( Jibson, 1989).

\section{GEOLOGY AND PHYSIOGRAPHIC SETTING}

The Chuuk Islands are the erosional remnants of a partly submerged large shield volcano, long since inactive. These remnants largely consist of basaltic, andesitic, and trachytic lava flows, however, pyroclastic deposits are locally interbedded with the flows. The volcano extends from the ocean floor which is about 5,000 $\mathrm{m}$ below, to the water surface and was formerly several thousand feet above sea level. Coral reefs now form a surrounding barrier at the volcano's margins at the water surface while fringing reefs border the volcanic islands within the lagoon. No traces exist of crater or caldera walls marking a central volcanic vent. However, geologic evidence indicates a central crater that produced large volumes of pyroclastic ejecta that now appears as volcanic breccia (Stark and Hay, 1963).

The Chuuk Islands comprise small volcanic and reef islands in a lagoon (formerly called Truk Lagoon) formed by a coral reef (fig. 2). They are divided into an eastern group (Weno, Tonoas, Fefan, and Uman), a central group (Udot and Eot), and a western group (Tol, Fanapanges, and Romonum). The high volcanic islands range in size from about $30 \mathrm{~km}^{2}$ (Tol-8 $\mathrm{km} \times 3.2 \mathrm{~km}$; Weno- $6.4 \mathrm{~km} \times 4.8 \mathrm{~km}$ ) to the smallest islands which are less than $0.5 \mathrm{~km}$ in diameter. The highest elevation on Tol is $446 \mathrm{~m}$; the highest elevations on Weno and Tonoas are $369 \mathrm{~m}$ and $344 \mathrm{~m}$, respectively. Slopes, in general, average 
Significant landslides in Chuuk State, Federated States of Micronesia, triggered by tropical storm Chata'an

\begin{tabular}{|c|c|c|c|c|c|c|}
\hline $\begin{array}{l}\text { Map } \\
\underline{\text { number }}\end{array}$ & Location & $\underline{\text { Island }}$ & $\frac{\text { Number of }}{\underline{\text { Fatalities }}}$ & $\underline{\text { Other Significance }}$ & $\frac{\text { Est imated Volume }}{\underline{\left(\mathrm{m}^{3}\right)}}$ & $\frac{\text { Description in }}{\underline{\text { text }}}$ \\
\hline 1 & Nepukos & Weno & 3 & Destroyed houses & 20,000 & $*$ \\
\hline 2 & Mwan & Weno & 1 & Destroyed houses & 10,000 & $*$ \\
\hline 3 & Nechap & Tonoas & 14 & Destroyed houses & 100,000 & * \\
\hline 4 & Kuchua & Tonoas & 5 & Destroyed houses & 200,000 & * \\
\hline & & & & Destroyed water supply & & \\
\hline 5 & Roro & Tonoas & & reservoir & 100,000 & $*$ \\
\hline 6 & Enin & Tonoas & 5 & Destroyed houses & 1000 & \\
\hline 7 & Chun & Tonoas & & Destroyed dispensary & 3000 & \\
\hline 8 & Pwene & Fefan & 2 & & 28,000 & * \\
\hline 9 & Meseiku & Fefan & 2 & Destroyed house & 100 & \\
\hline 10 & Sapore & Fefan & 4 & Destroyed houses & 10,000 & * \\
\hline 11 & Mochon & Uman & & Very large volume & $1,500,000$ & \\
\hline 12 & Sanuk & Uman & 1 & Destroyed houses & 10,000 & * \\
\hline 13 & Fanai & Siis & 1 & & & \\
\hline 14 & Penia & Udot & 4 & Destroyed houses & $10-15,000$ & * \\
\hline 15 & Mwalitiw & Udot & 1 & Destroyed houses & & \\
\hline 16 & Faia & Fanapanges & & $\begin{array}{c}\text { Destroyed houses and } \\
\text { dispensary }\end{array}$ & 8000 & $*$ \\
\hline & & $\begin{array}{c}\text { Total } \\
\text { Fatalities }\end{array}$ & 43 & & & \\
\hline
\end{tabular}

of the volcanic islands have small streams originating in the steeper uplands and have flat coastal lowlands around their margins. These lowlands are commonly narrow, but on some islands they are wider than $0.5 \mathrm{~km}$. In addition, 24 low coralreef islands are within the lagoon. The surrounding barrier reef is capped by by 41 low coral islands. The largest is slightly longer than $3 \mathrm{~km}$ and about $0.5 \mathrm{~km}$ wide with most being much smaller (Stark and Hay, 1963). Landslides triggered during tropical storm Chata'an occurred predominantly on the steeper parts of the volcanic islands.

\section{LANDSLIDES TRIGGERED BY CHATA'AN}

\section{Types of Landslides}

Many types of landslides were triggered during tropical storm Chata'an. The landslide nomenclature used in this report is from Varnes (1978). Debris flows caused the most death and destruction. Most debris flows on the islands of Chuuk State originated from rotational slumps; a few originated from shallow translational landslides. These landslides were triggered by rainfall infiltrating into the ground, increasing ground-water pressures, and weakening the slopes. Most of the initial landslides occurred on slopes steeper than $20^{\circ}$. Many saturated or nearly saturated slumps then transformed into debris flows, raced down steep slopes, traveled across the coastal flats, and came to rest leaving thick deposits of saturated mud, boulders, and debris. Figure 4 shows a slump (landslide source), debris-flow track, and debris deposit at Mwan (no. 2, pl. 1) on the island of Weno.

Rotational slumps triggered during the storm varied in depth from 1 to $40 \mathrm{~m}$, and were composed primarily of deeply weathered basaltic- and andesitic-volcanic rocks with some surficial colluvium. Sliding surfaces commonly occurred near the contact between weathered and unweathered volcanic rocks. Slides were not present in hard, unweathered bedrock. Some of the landslides, generally those on steeper slopes with shallow colluvium underlain by stronger bedrock, originated as thin, slab-like translational slides. Most of the damaging debris flows originated as deep rotational slumps in highly weathered bedrock. The most damaging significant landslides are discussed in the section on significant landslides below.

At several sites, the initial slump or slide block dammed 5 


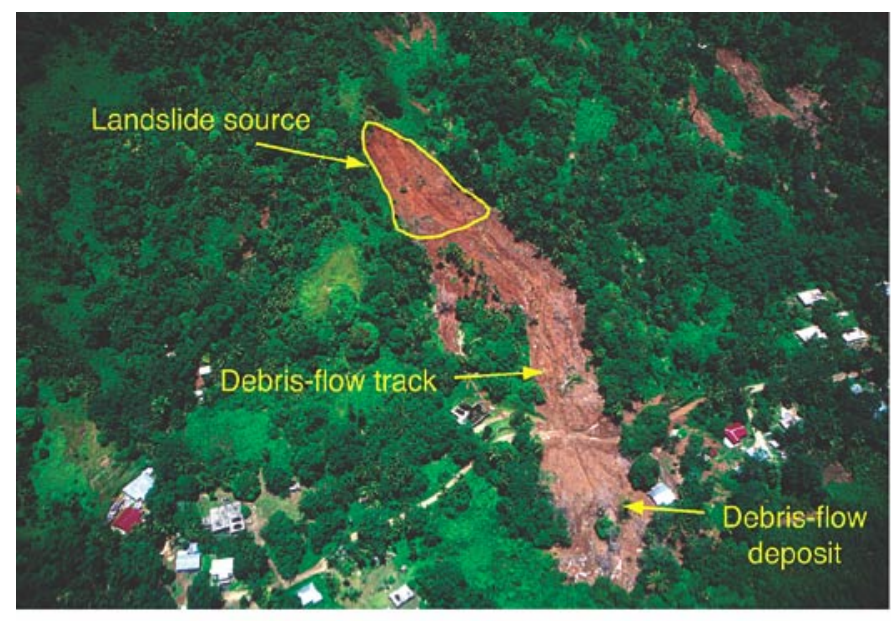

A.

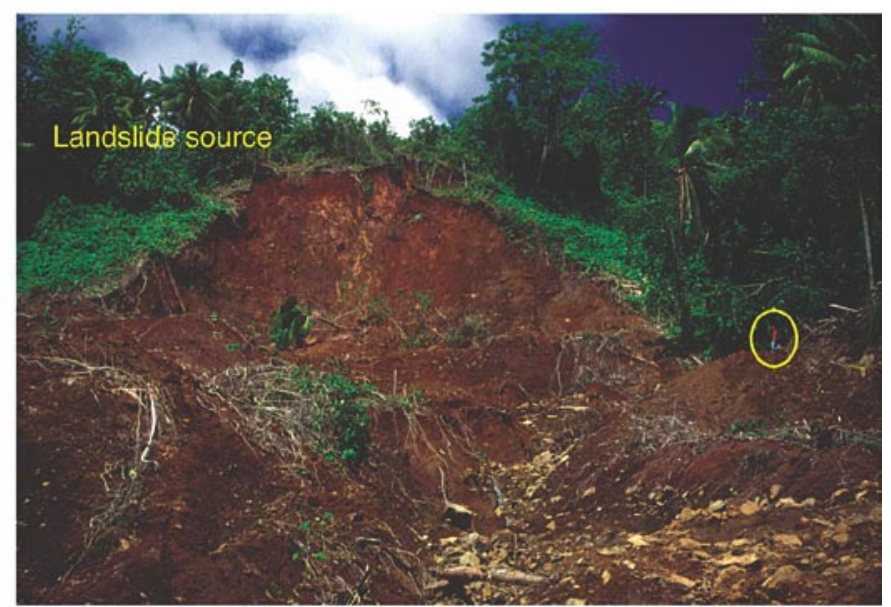

B.

Figure 4. A. Oblique aerial photograph of Mwan slump/debris flow showing the location of the landslide source, debris-flow track, and debris-flow deposit. B. Landslide source (slump) for the Mwan debris flow. Yellow circle locates person for scale.

scarp and then mobilized as a debris flow as the landslide dam was overtopped by the impounded water. This was the case in the large and particularly destructive debris flows at Nechap, Kuchua, and Roro (nos. 3, 4, and 5, pl. 1) on the island of Tonoas where the impounded water appeared to be a major factor in the mobilization of the landslide masses into highspeed slurries.

\section{Landslide Inventory}

We produced an inventory map showing the size and distribution of landslides triggered by tropical storm Chata' an on the islands of Weno, Tonoas, Fefan, Uman, Etten, Udot, Eot, and Fanapanges (pl. 1). The few landslides on the islands of Siis and Tol were not mapped. With two exceptions, on southern Fefan Island and on Fanapanges Island, incipient landslide cracks also were not mapped. Landslide-source areas and their deposits were located and plotted using surveys from small aircraft, boat, foot, and automobile. Hand-held photographs taken during a 2.5 hour overflight of the volcanic islands on August 6, 2002, were particularly useful; these photographs were used to map landslide boundaries onto 1 : 25,000-scale topographic maps of the islands. Although these oblique aerial photographs were useful in locating the landslides, the lack of complete stereographic-photographic coverage limits the location accuracy to about 10-100 m. In addition, some of the smaller landslides were undoubtedly missed because of the lack of vertical view of the entire land surface. Plate 1 illustrates the extensive landsliding produced by Chata'an; 269 landslides are shown.

We compiled statistics on the landslides shown in plate 1 using Geographical Information System (GIS) analysis. Table 1 shows the number of mapped landslides on each island, the area affected by landslides, and the amount of the coastal lowlands affected by landslides. We defined the coastal lowlands as encompassing relatively flat land lower than $10 \mathrm{~m}$ in elevation; these coastal flats are where most residents live. The greatest number of mapped landslides occurred on Fefan (96), followed by Weno (64) and Tonoas (57). However, Tonoas had the greatest area affected by landslides (almost 8 percent of the island) and the majority of fatalities ( 24 of 43 total) (see "Significant Landslides" section below).

\section{Debris-Flow Runout}

The distance debris flows travelled across gently sloping ground and the coastal flats was extremely important in causing damage to people and property during Chata'an. Most of the population of the volcanic islands reside on the flat coastal shorelines of the islands. The degree of damage wrought by landslides was linked directly to the runout length of debris flows that invaded these areas of highest population density. Runout distances depended on the volume of the source landslide and the slope steepness below the source areas; large initial volumes and steep slopes resulted in longer runouts. Using the landslide-inventory map (pl. 1), we measured and compiled runout distances for all debris flows that had significant runout. Runout was defined as the distance a debris flow traveled after it reached a distinctive break in slope below its source, identifiable on the topographic base of plate 1. For longer flows, part of this runout is across the coastal flats. Figure 5 shows a bar graph of the runout distances of 72 debris flows that had a flow path that could be measured. The range of runout distances varied from a low of $10 \mathrm{~m}$ to a maximum of about $700 \mathrm{~m}$. The average runout distance was $89 \mathrm{~m}$. 


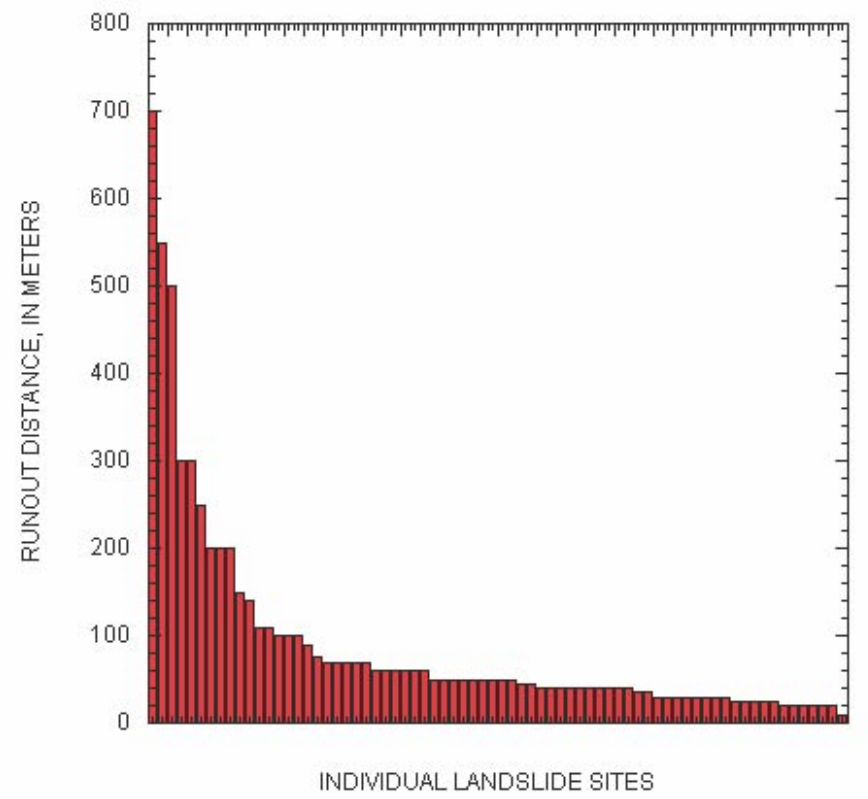

Figure 5. Bar graph showing horizontal runout distances of 72 individual debris flows triggered by tropical storm Chata'an. Distances were determined from the topographic base map used for Plate 1.

\section{SIGNIFICANT LANDSLIDES}

Although at least 269 landslides were triggered by Chata'an, only a few of these landslides resulted in death and extensive property damage. Table 2 lists significant landslides caused by Chata'an that resulted in human fatalities, were particularly large, or destroyed public facilities such as water reservoirs, or medical dispensaries. Many of these slides also crushed homes and community centers, damaged local water supplies (commonly springs), downed power lines, buried agricultural crops, and blocked roads or trails. All of these sites were visited on the ground by USGS scientists, except for the Fanai landslide on the island of Siis and the Mwalitiw landslide on Udot, which are not identified on plate 1. The Fanai landslide on the island of Siis was not mapped because we did not visit this island, and the Mwalitiw landslide on the island of Udot was not identified because of imprecise information from local sources. Landslide volumes were estimated in the field. Fatality numbers were obtained from the Chuuk State Office of Vital Statistics as of August 6, 2002, and were later confirmed in consultation with Dr. Carlos Sanchez of the U.S. Centers for Disease Control and Prevention. Both large landslides (such as the Kuchua landslide on the island of Tonoas, no. 4, pl. 1) and rather small landslides (such as the Meseiku landslide on the island of Fefan, \# 9, Plate 1) caused fatalities. However, some extremely large landslides (such as the Mochon landslide on Uman, no. 11, pl. 1) did not cause any deaths. Fatalities occurred where people were sheltered or traveling directly in the path of oncoming large or small debris flows. Estimates of homes and structures damaged or destroyed were obtained from local residents. Other landslides, not described below, also damaged or destroyed homes, water supplies, power lines, crops, and roads. The following sections describe some of the significant landslides and also discuss potential short-term hazards posed at these landslide sites. Location numbers refer to landslides listed in table 2 and shown on plate 1 .

\section{Weno (Moen) Island}

\section{Nepukos Slump/Debris Flow—Map Location 1}

Above Nepukos village on the western side of Weno Island, Chata'an triggered a slump that transformed into a debris flow; this flow overran five houses, a road, and powerline at the base of the slope, caused three fatalities, and continued about $70 \mathrm{~m}$ out onto coastal flats and into mangrove swamps. The initial slump of about $20,000 \mathrm{~m}^{3}$ occurred on a knoll with a slope of about $35^{\circ}$ at the end of a ridge (fig. 6). The headscarp of the slump was about $10 \mathrm{~m}$ high and $30 \mathrm{~m}$ wide at its base. The slump occurred in weathered, clay-rich volcanic rocks. The landslide scar and remaining debris are now well drained and eroded so that water emanating from the headscarp flows in a well-developed channel. Future rainfall could generate some smaller failures from the headscarp; however, such failures are not likely to travel beyond the immediate headscarp area.

\section{Mwan Slump/Debris Flow-Map Location 2}

This slump/debris flow occurred inland from the village of Mwan on the island of Weno (fig. 4) and resulted in one fatality. As with the Nepukos landslide, the Mwan landslide began as a slump in weathered volcanic rocks on a $35^{\circ}$ slope and transformed into a rapidly moving debris flow. The flow traveled about $100 \mathrm{~m}$ downslope along a stream channel and buried a road and water well at the base of the slope. The debris flow also may have incorporated additional material from the stream channel. It then flowed onto flatter ground, destroyed a house, and stopped about $60 \mathrm{~m}$ downslope of the road. The initial slump, about $50 \mathrm{~m}$ high, had an approximate volume of $10,000 \mathrm{~m}^{3}$. Clay-, sand-, and boulder-rich landslide deposits remain along the sides of the stream channel and in the depositional area downslope of the buried road. Drainage channels have been eroded into remnants of the landslide debris in the slide scar. Two small incipient slumps remain adjacent to each side of the initial headscarp; they have volumes of about 1,000-2,000 $\mathrm{m}^{3}$ each. Both incipient slumps have undergone about 3 to $4 \mathrm{~m}$ of displacement. Future heavy rainfall may reactivate these incipient slumps; however, it is doubtful that they will cause additional damage in the short term. Any newly mobilized materials likely will be small and will be impeded by the rough, irregular slide surface. 


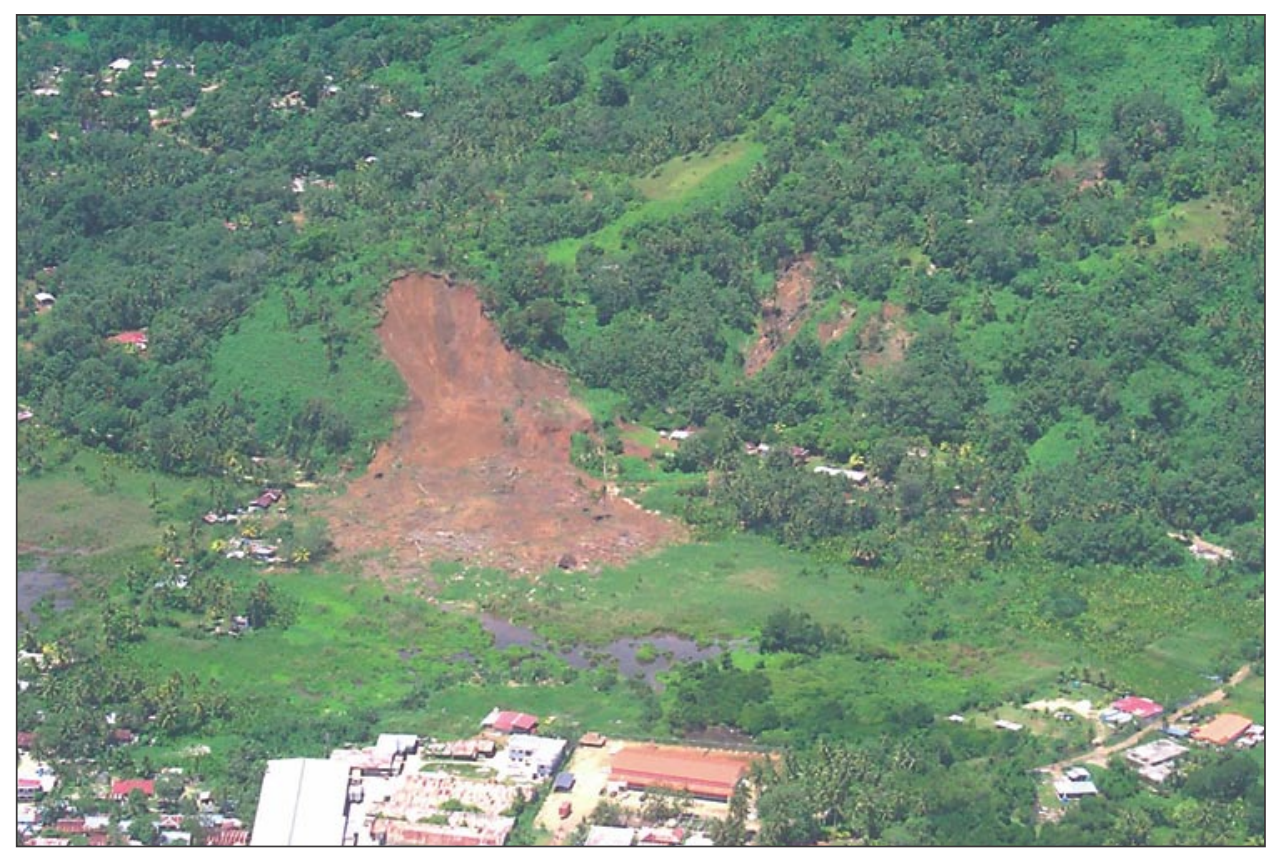

Figure 6. Oblique aerial photograph of Nepukos slump/ debris flow on the island of Weno.

\section{Tonoas (Dublon) Island}

\section{Nechap Area Slump/Debris Flow_Map Location 3}

One of the largest landslide disasters transpired in the village of Nechap on the island of Tonoas. Here, residents reported that debris flows caused 14 fatalities and destroyed 31 dwellings, a water-supply system, and powerlines (fig. 7). Concrete water tanks were transported more than $100 \mathrm{~m}$ out to the ocean's edge by the flows. The damaging landsliding began as two slumps in weathered volcanic rocks, with a combined volume of more than $100,000 \mathrm{~m}^{3}$. These slumps mobilized into rapid debris flows; deposits from these flows cover a road and extend across the flat coastal lowland for about $175 \mathrm{~m}$ and into the ocean (figs. 8 and 9). The lower slump of approximately $75,000 \mathrm{~m}^{3}$ has a slope width of about $90 \mathrm{~m}$, a scarp height of $120 \mathrm{~m}$, and an average thickness of $7 \mathrm{~m}$. The upper slump mass has a width of about $70 \mathrm{~m}$, a scarp height of $50 \mathrm{~m}$, and a thickness of about $7 \mathrm{~m}$. The upper slump mass initially impounded water draining from the landslide scarp and formed a rapidly moving slurry of soil and weathered rock (debris flow) as the impounded water breached the slump mass. The debris flow from the upper slump evidently occurred after the debris flow from the lower slump mass, because it forms a lobate deposit that overlies the debris deposit from the lower slump.

Both of the slumps failed completely, meaning that most or all, of the slide material within the source areas underwent many meters of displacement. Much of the slump material was remobilized into a debris flow, and the scarp area now is well drained. The likelihood of additional large failures from these scarps is low. Remaining debris-flow material, which extends to the ocean, likely will be eroded by future rainfall and surface runoff. The continuing hazard to people living near these deposits is low. Nearby, two smaller slumps (one about $200 \mathrm{~m}$ to the east and another about $100 \mathrm{~m}$ to the west) are each about one-fifth of the combined volume of the larger flows. These slumps also failed completely, but they only partially mobilized into debris flows. The continuing hazard to people living on the coastal lowlands near the toes of these landslides also is relatively low.

\section{Kuchua Slump/Debris Flow-Map Location 4}

This landslide is one of the largest triggered by tropical storm Chata' an (fig. 10). The landslide and resulting debris flows resulted in five fatalities and six homes destroyed. The headscarp of the source slide is about $150 \mathrm{~m}$ wide, $150 \mathrm{~m}$ long in the downslope direction, and $10 \mathrm{~m}$ in average thickness, resulting in a total volume of approximately $200,000 \mathrm{~m}^{3}$. The slope of the headscarp area, prior to failure, was approximately $30^{\circ}-40^{\circ}$. The failure surface is arcuate in cross section, and initial movement of this mass apparently resulted in the temporary impoundment of a large volume of water draining from the scarp and possibly surface gullies. In addition to impounded water infiltrating the slump mass, catastrophic failure likely resulted from overtopping of the slump mass by the impounded water, and/or from piping and subsequent rapid failure. The catastrophic failure mobilized much of the slump material, and the resulting flows cut a deep erosion channel through the slump. This channel exits at the east side of the source area and indicates where mixed water and debris flowed out of the source area. According to Chester Gustav, who lives near the distal end of the debris flow, the first wave of debris and water arrived at 10:00 a.m. on July 2, followed by two more waves of debris. The entire debris-flow activity took place over 26 minutes. The distal end of the debris flow 

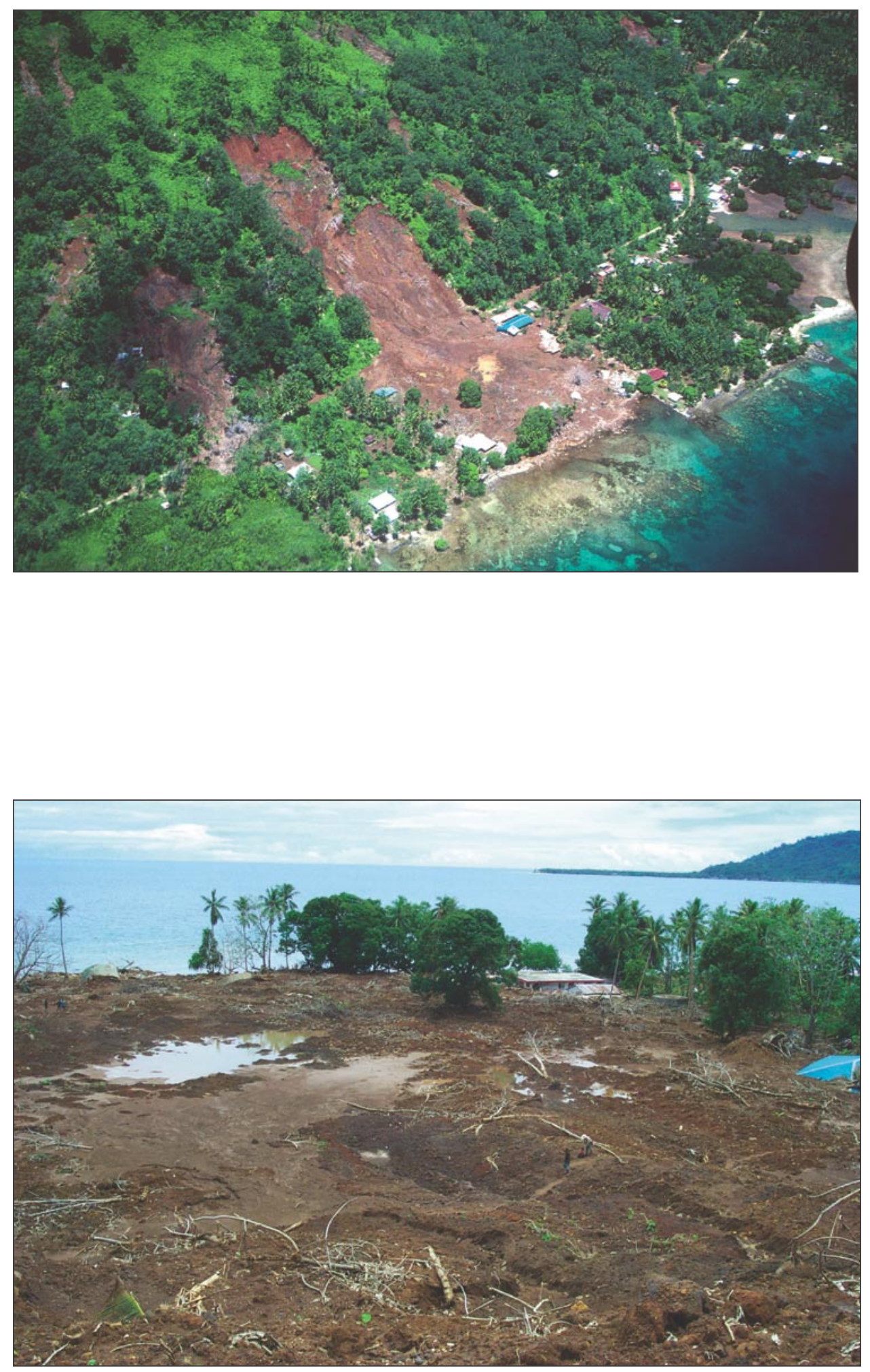

Figure 7. Oblique aerial view of Nechap slump/debris flow on the island of Tonoas.

Figure 8. Deposits from Nechap debris flow showing destroyed homes and displaced concrete water tanks (upper left in photo near shoreline). 


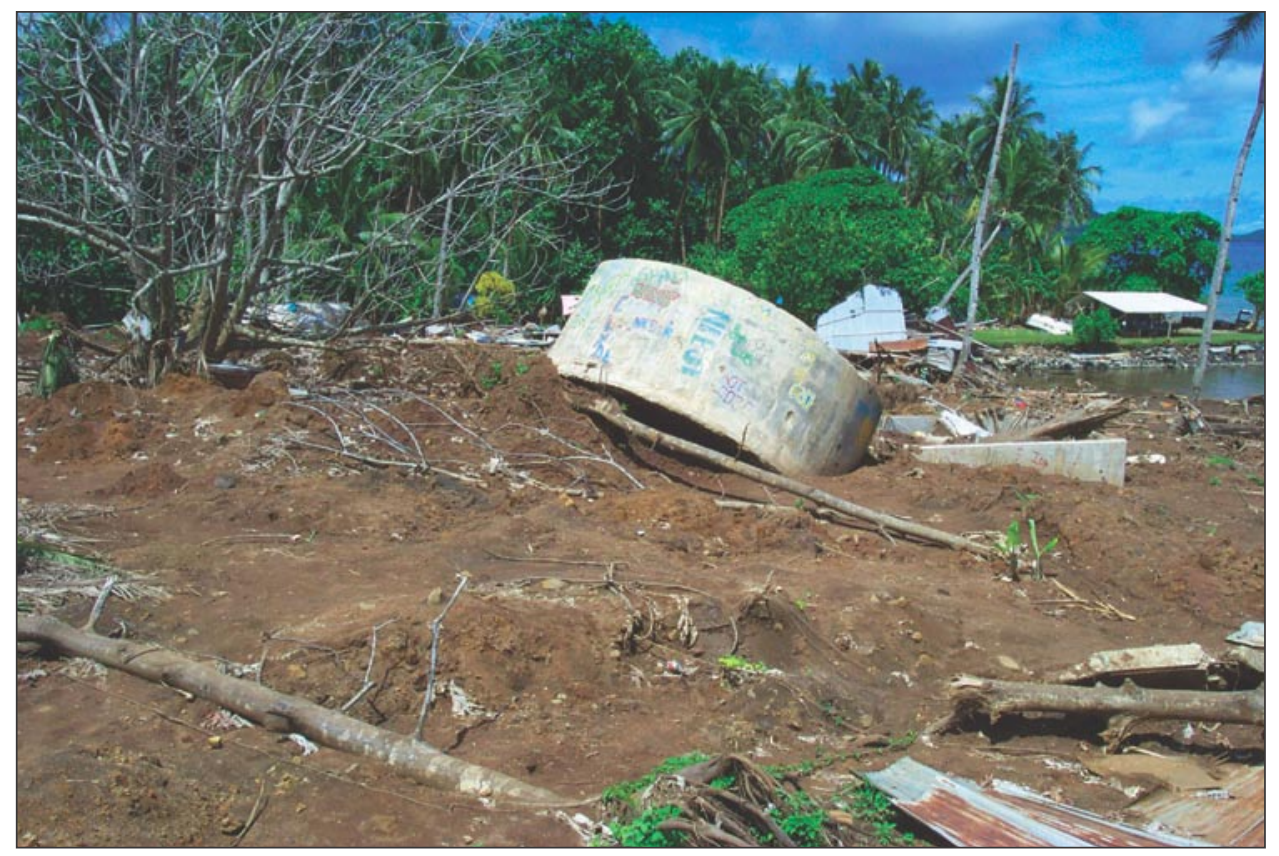

Figure 9. Distal part of Nechap debris flow, near the ocean, showing debris from destroyed houses and closeup of water tank.

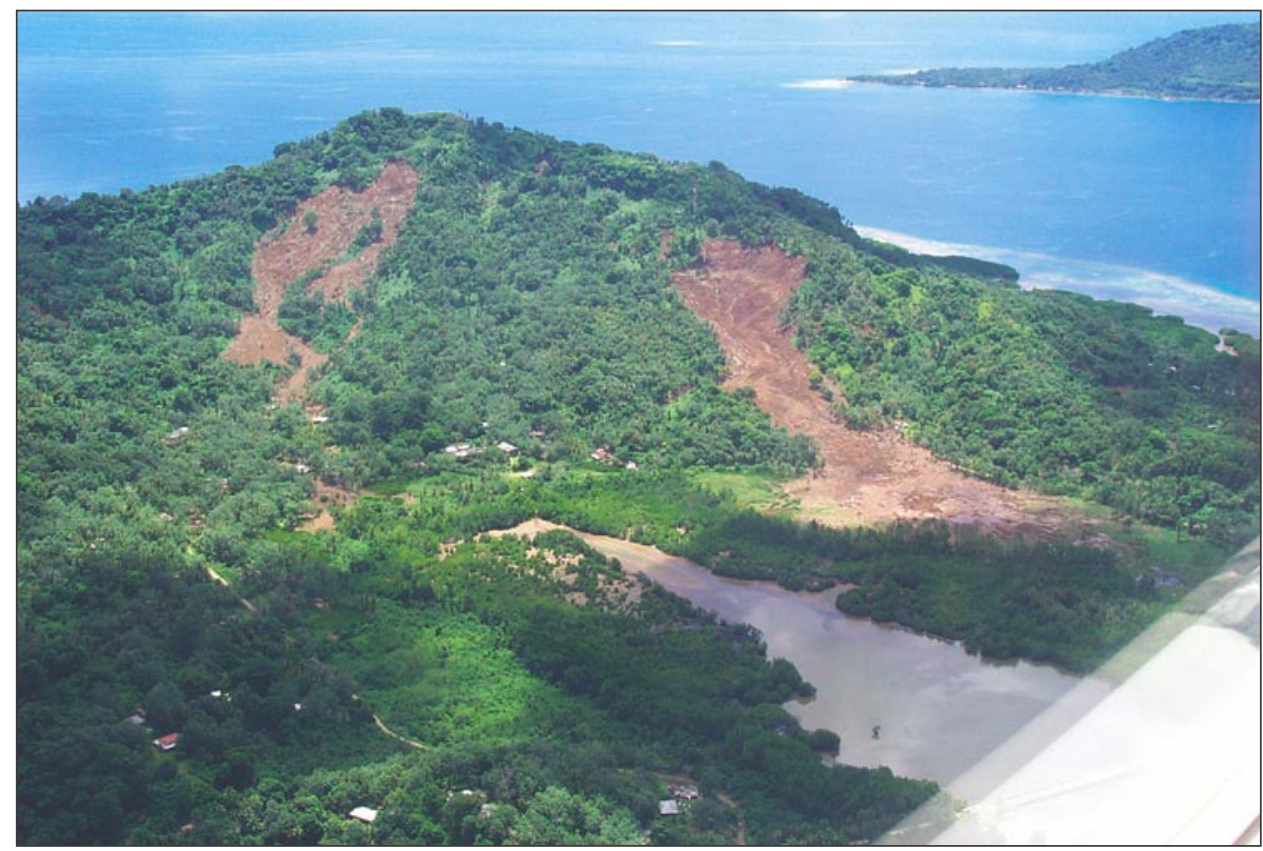

Figure 10. Oblique aerial view of Kuchua slump/debris flow (right) and Roro debris slide/flow (left) on the island of Tonoas. 


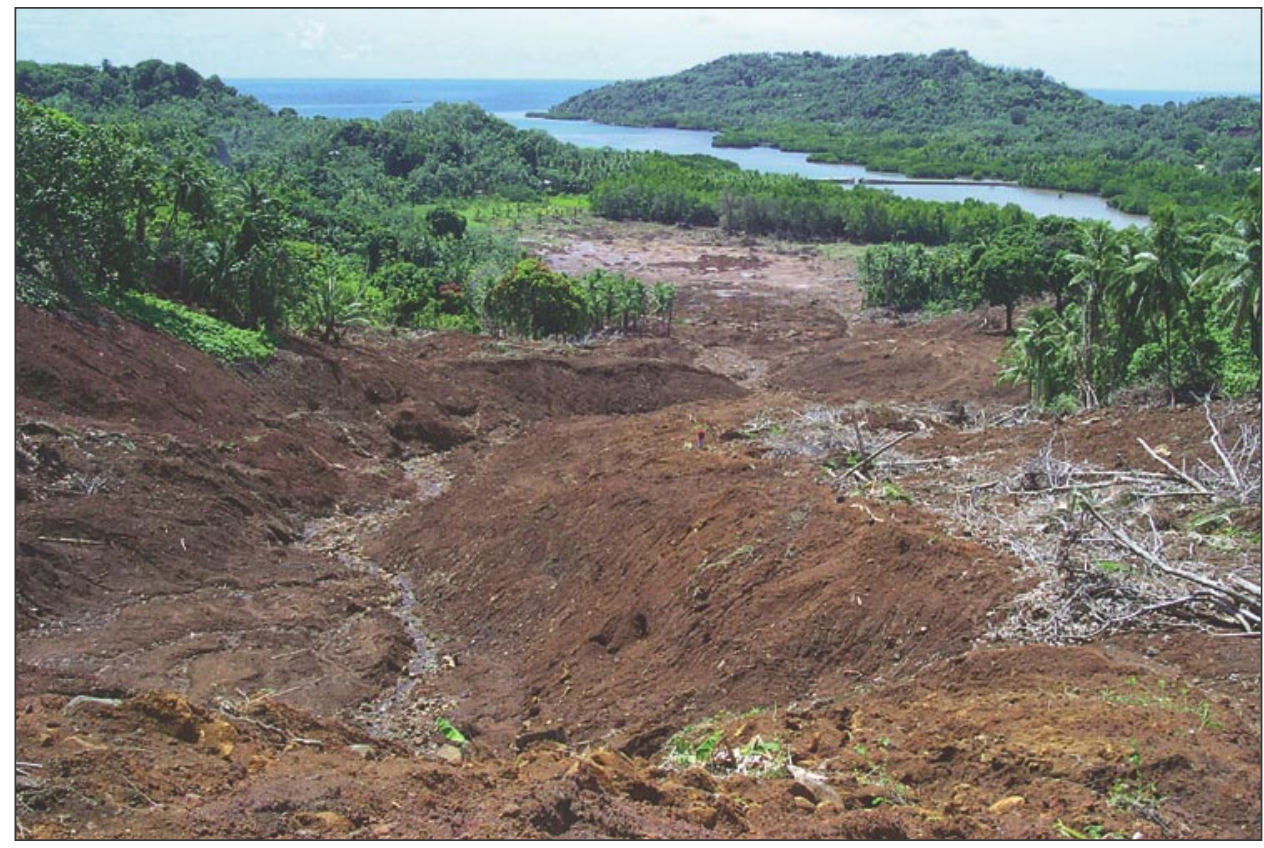

Figure 11. Downslope view of Kuchua slump/debris-flow path. Deposits from this flow covered taro fields at the distal end of the deposit.

extended about $500 \mathrm{~m}$ into the taro field beyond the break in slope at the base of the flow path (figs. 10 and 11). The overall length of the flow is greater than $700 \mathrm{~m}$. The headscarp area has relatively low continuing landslide hazard. Farther down the flow path, considerable debris remains along the west side of the main channel of flow. These slopes are relatively gentle $\left(\sim 15^{\circ}\right)$, however, and are unlikely to remobilize into massive debris flows.

\section{Roro Debris Slide/Flow-Map Location 5}

Another large landslide occurred approximately $500 \mathrm{~m}$ to the southwest of the Kuchua landslide. Here, the headwaters of a stream catchment basin were denuded of vegetation and surficial material by a complex of several thin (1-2 m thick), planar debris slides totaling about $100,000 \mathrm{~m}^{3}$ (fig. 10). The upper part of this large debris-slide complex transformed into a flow or multiple flows and traveled down two main channels. These two channels coalesced downstream, shortly upstream of a 3-m-high water-catchment structure. Debris flows overran and filled this structure, burying water-supply pipes (fig. 12); flows then traveled downstream into a small community of houses. The largest (western) lobe of the source slide shows evidence of having briefly dammed a small stream; catastrophic breaching of this debris dam likely resulted in one of the coalescing debris flows.

\section{Fefan Island}

\section{Pwene Slump/Debris Flows-Map Location 8}

Near the school in the village of Pwene (Wininis), two children were killed by a debris flow on the afternoon of July 2. Here, two slumps failed from a $30^{\circ}$ slope above the school and coalesced to produce a $28,000 \mathrm{~m}^{3}$ debris flow (figs. 13 and 14). A 50-m-wide tree covered ridge that did not fail during the storm separates the two slump sources. The debris flow spread out across a nearly flat field behind the school. The slumps underwent extensive mobilization into debris flows, and little material remains in the headscarp area.

\section{Sapore Slump/Debris Flow and Incipient Landslide-Map Location 10}

On the southern end of the island of Fefan, a slump/debris flow buried a road, destroyed nine homes, and killed four people during Chata'an (figs. 15 and 16). The slump originated on slopes of $35^{\circ}$ and moved about $10,000 \mathrm{~m}^{3}$ of weathered volcanic rock before transforming into a debris flow. Most of the slump material has undergone 5-10 $\mathrm{m}$ of displacement, and any additional movement likely will be small and confined to the source area. The headscarp of a large incipient slide extends from this slump scar northward along the hillslope for at least $500 \mathrm{~m}$. This scarp has recent vertical displacement of 2-3 m (Figure 17), although older roots near the slump scar suggest that at least part of the scarp was preexisting. A $15 \mathrm{~m}$-long toe is present below this scarp about $300 \mathrm{~m}$ from the slump where the slump mass has overthrust the ground surface by about $0.5 \mathrm{~m}$. Several houses are located near and downslope of the toe. Future behavior of this large incipient landslide is uncertain. It may undergo renewed movement with future rainfall. However, the depth of this slump is estimated to be $15-25 \mathrm{~m}$, and such a deep-seated landslide of this volume would be unlikely to move in response to light or moderate rainfall. Reactivation of this landslide may require abnormally high rainfall intensities and longer durations such as that provided by tropical storm Chata'an. 


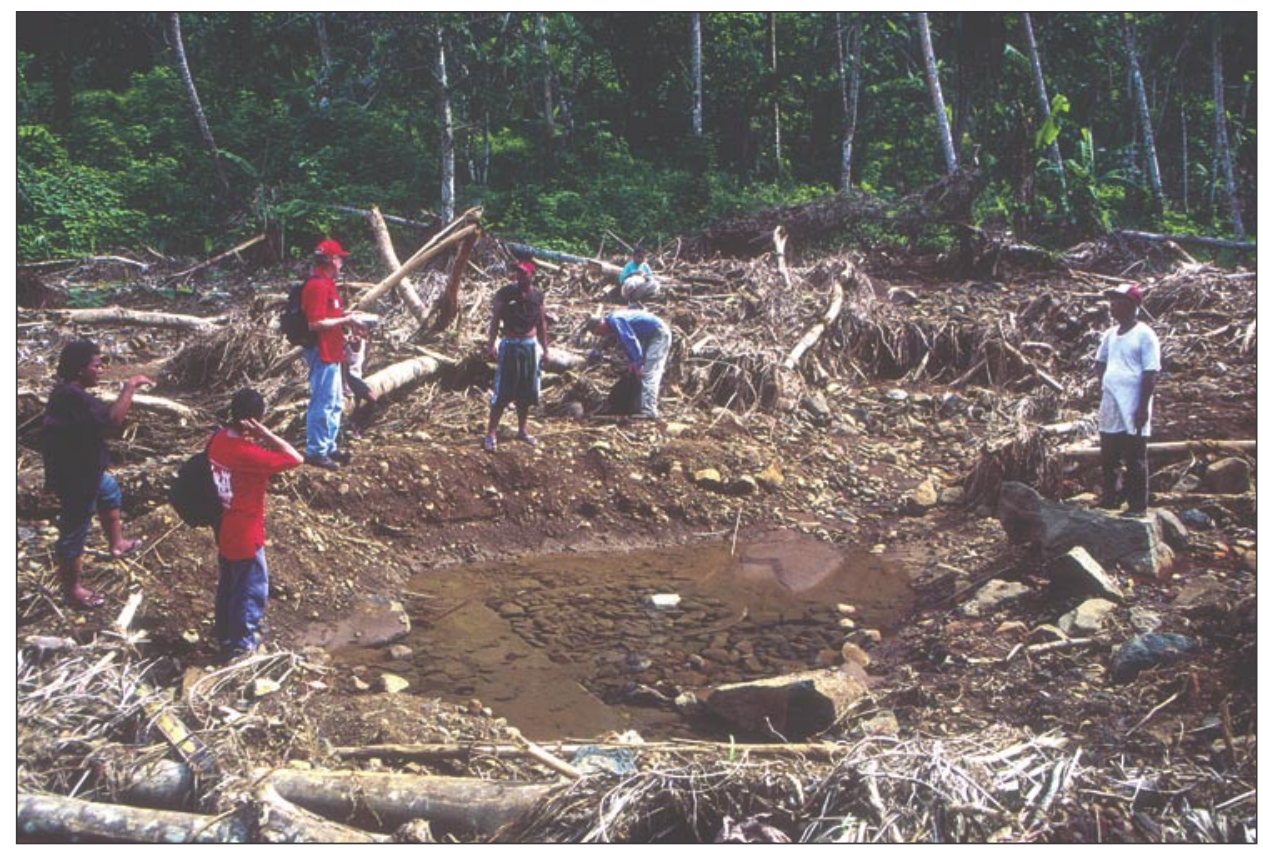

Figure 12. Water catchment basin inundated by debris from the Roro debris slide/flow. Part of the basin wall (in the small pond) has been exposed by digging after the debris flow event.

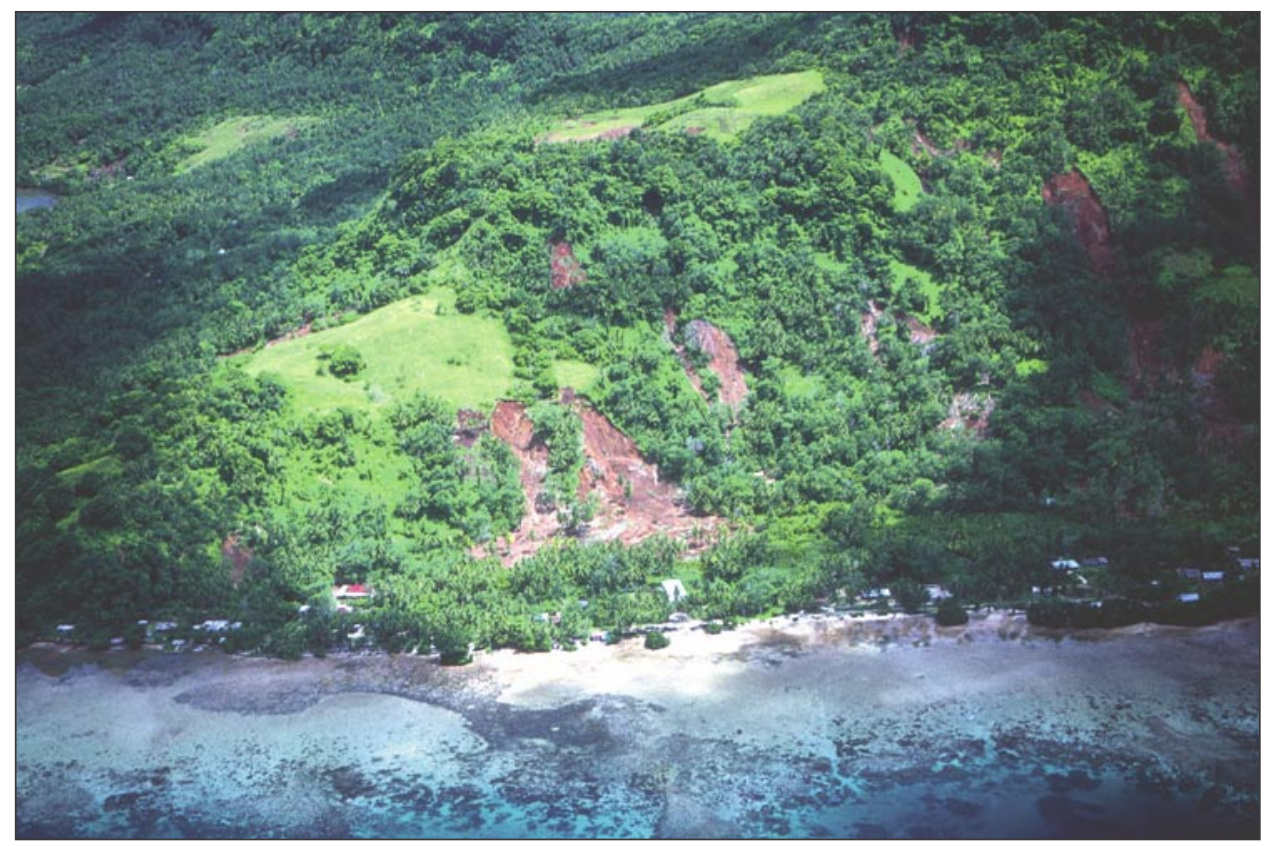

Figure 13. Aerial view of Pwene slump/debris flow on the island of Fefan. This site shows a debris-flow doublet (center of photo) with a downslope line of trees located on a ridge between the two debris flows that coalesced. 


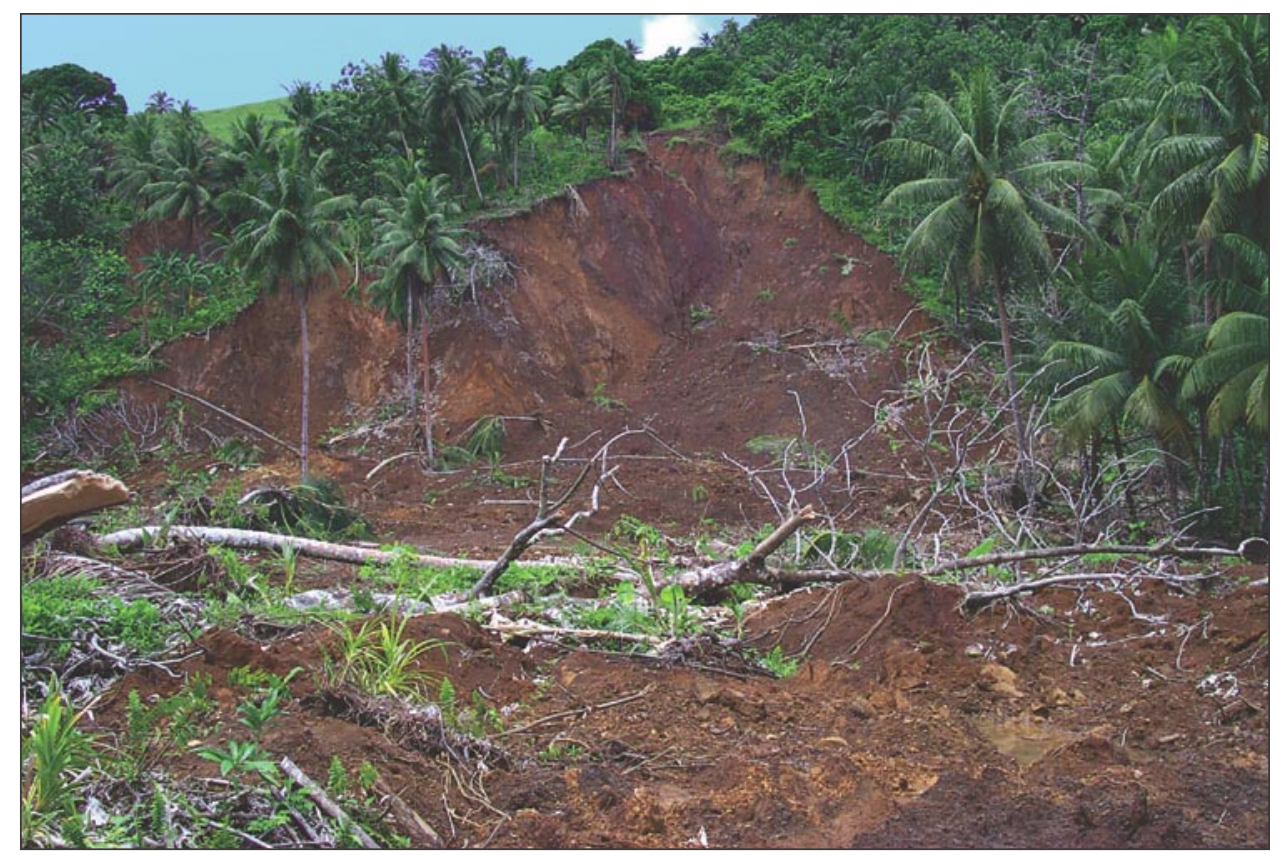

Figure 14. Head scarp of the northern Pwene slump/debris flow.

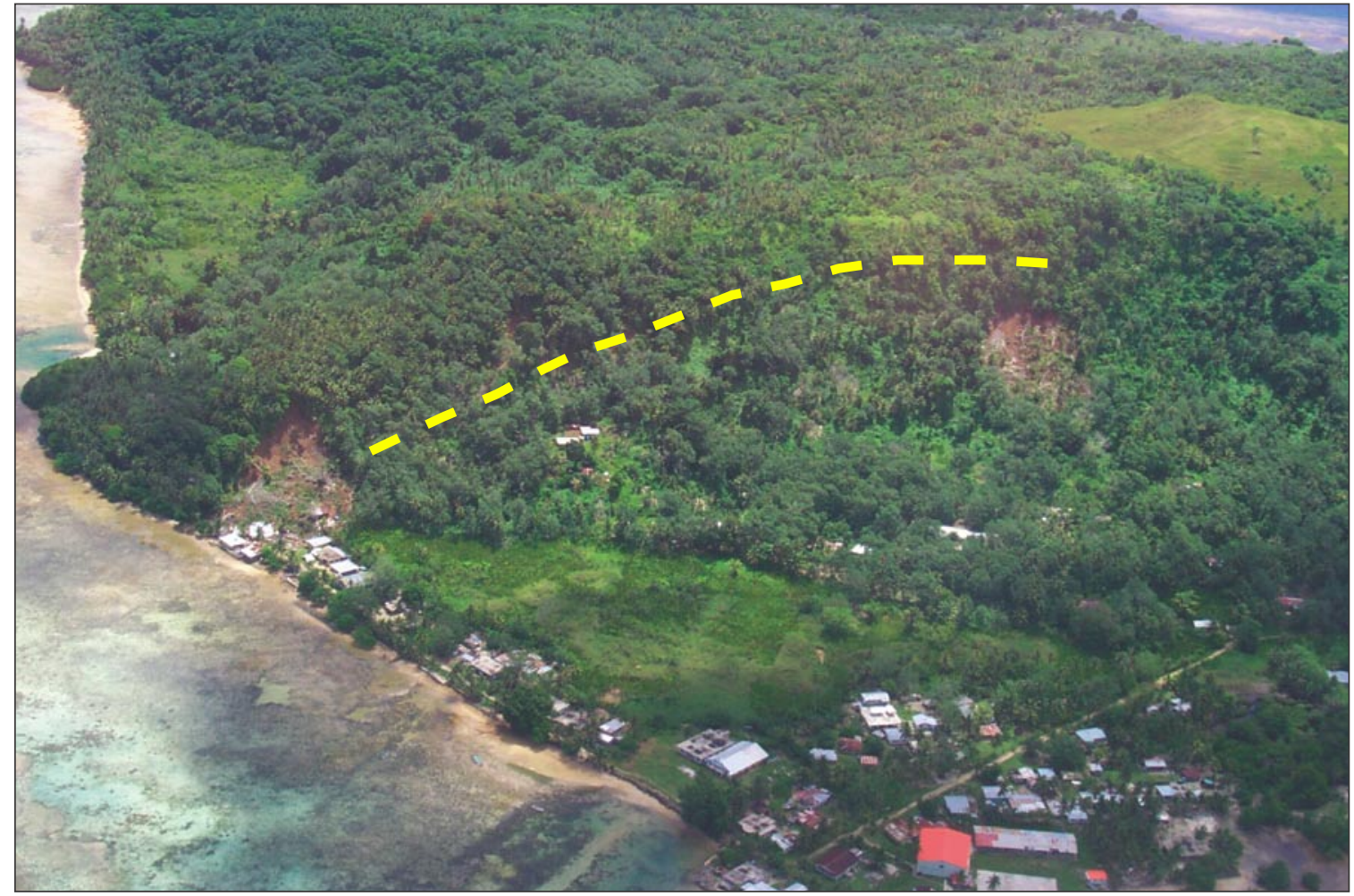

Figure 15. Oblique aerial view of Sapore slump/debris flow (left center) on the island of Fefan. Dashed line indicates approximate position of reactivated head scarp of preexisting large incipient slump. Preexisting slump mass is below and to the right of dashed line. 


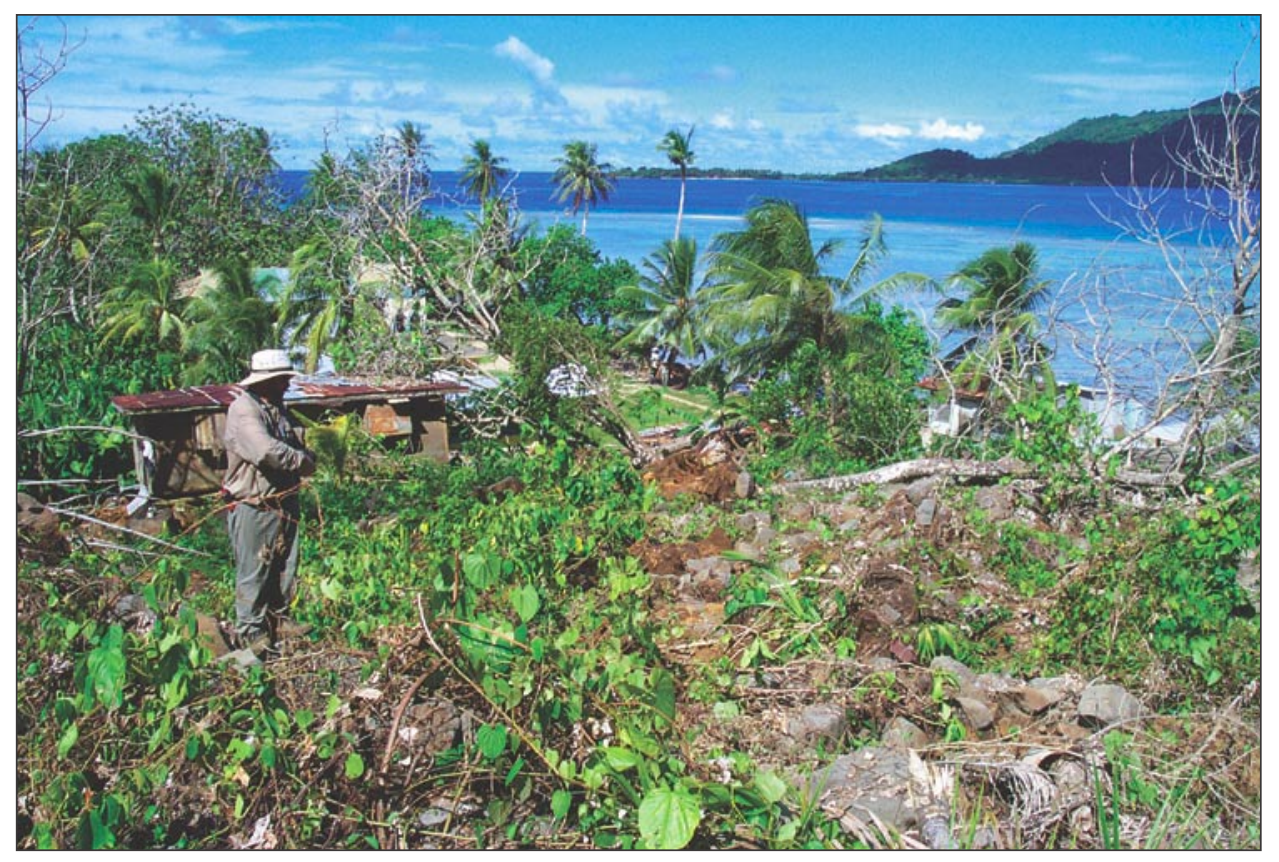

Figure 16. Downslope view of Sapore debris flow showing area where nine houses were buried or destroyed by the deposit.

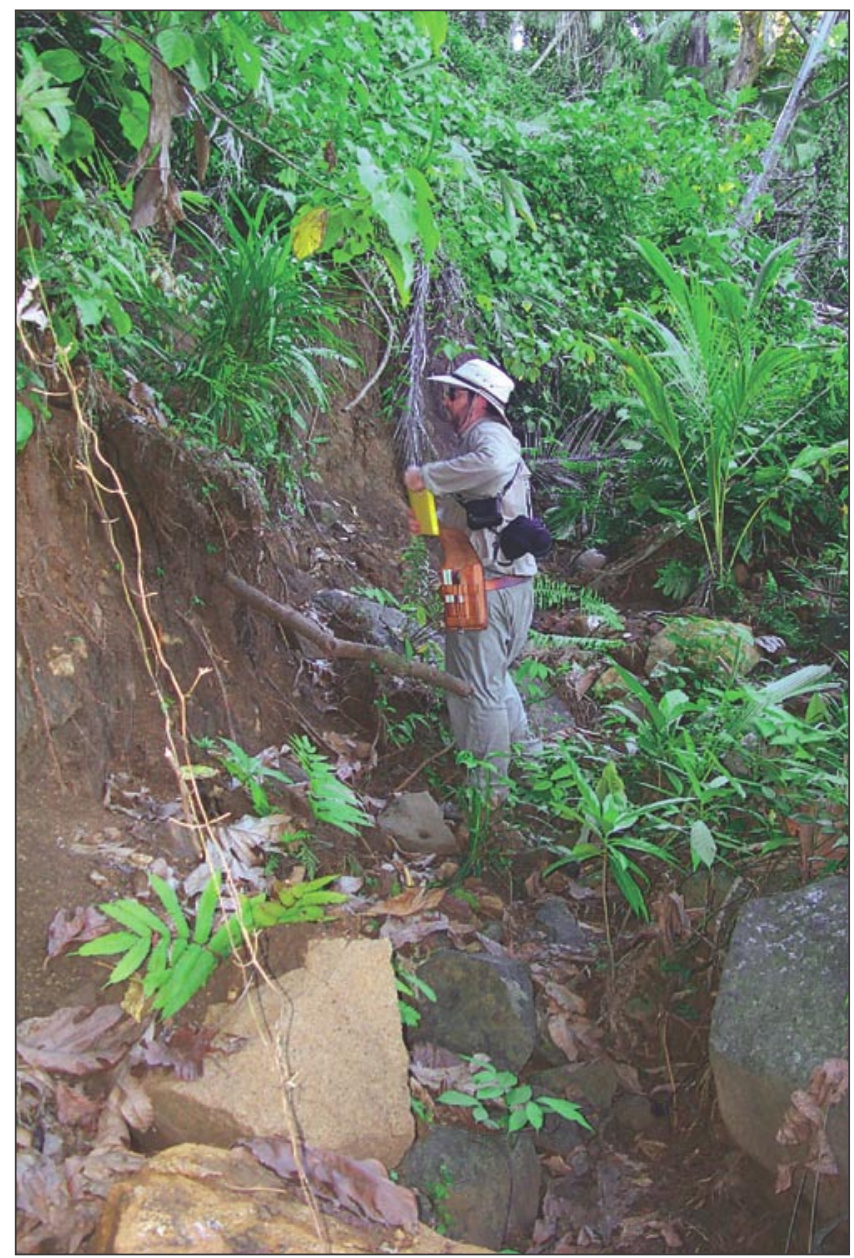

Figure 17. Scarp of reactivated large incipient slump (see fig. 15) near Sapore produced by rainfall from tropical storm Chata'an. 


\section{Uman Island}

\section{Sanuk Slump/Debris Flow-Map Location 12}

On the northeastern coast of the island of Uman in the village of Sanuk, another slump that transformed into a debris flow traveled across relatively narrow coastal lowlands. The debris flow buried 13 homes, a community center, a road, and caused one fatality. The 50-m high, $6,000 \mathrm{~m}^{3}$ - slump initiated on slopes of about $30^{\circ}$ in highly weathered volcanic rocks (fig. 18). After transforming into a debris flow, it traveled about $140 \mathrm{~m}$ downslope to the coastal lowlands and incorporated about $4,000 \mathrm{~m}^{3}$ of colluvium and weathered bedrock along its travel path. The resulting total volume of the flow deposit is about $10,000 \mathrm{~m}^{3}$. Some of the slump debris still remains in the slide source area; however, this material is unlikely to travel beyond the original source area due to small source volumes and roughness of the existing flow path.

\section{Udot Island}

\section{Penia Slump/Debris Flow-Map Location 14}

A slump located on the northwestern side of the island of Udot mobilized into a debris flow, traveled about $220 \mathrm{~m}$ downslope to the coastal flats, and caused four fatalities. The initial slump source had an 80 m-high scar and an estimated volume of 10-15,000 $\mathrm{m}^{3}$ (fig. 19). As with most of the other larger landslides triggered by Chata'an, the source area is located in deeply weathered, basaltic-volcanic rocks. According to local residents, this event occurred at about 7:00 or 8:00 a.m. on July 2. Small remnants of the original mass may mobilize in future intense rains but are unlikely to travel beyond the original source area.

\section{Fanapanges Island}

\section{Faia Slumps and Incipient Slumps- Map Location 16}

On the eastern coast of the island of Fanapanges, a continuous series of slumps and incipient slumps were triggered during Chata'an, again within highly weathered, basaltic-volcanic rocks. The entire complex affects at least $250 \mathrm{~m}$ of trail along the coastline. The northernmost of these slumps, $50 \mathrm{~m}$ in height, with a volume of about $8,000 \mathrm{~m}^{3}$, transformed into a debris flow and traveled about $100 \mathrm{~m}$ to the shoreline (fig. 20). This flow destroyed 15 homes, a water basin, and a dispensary in the village of Faia. According to local residents, this event occurred about 10:00 a.m. on July 2. Incipient cracking, with a vertical displacement of about 0.5 $1.5 \mathrm{~m}$, extends southward from the headscarp of this slump (A, fig. 21). Adjacent to this slump and below the incipient cracking is a relatively intact, wedge-shaped incipient slide, $60 \mathrm{~m}$ wide along the trail (B, fig. 21). South of this, shallow blocky failures from the toe of a larger slump extend for about $90 \mathrm{~m}$ along the trail and reach the coastline (C, fig. 21). According to residents, this slump occurred a few minutes after the destructive northern debris flow. To the south of this feature, incipient cracks curve and step shoreward, crossing the trail about $70 \mathrm{~m}$ south of recent slumps (D, fig. 21). During very wet periods, this entire area (about $250 \mathrm{~m}$ long) may be subject to renewed slumping and possibly debris-flow activity. This extensive area remains potentially hazardous and would be a relatively poor site for relocating a dispensary.

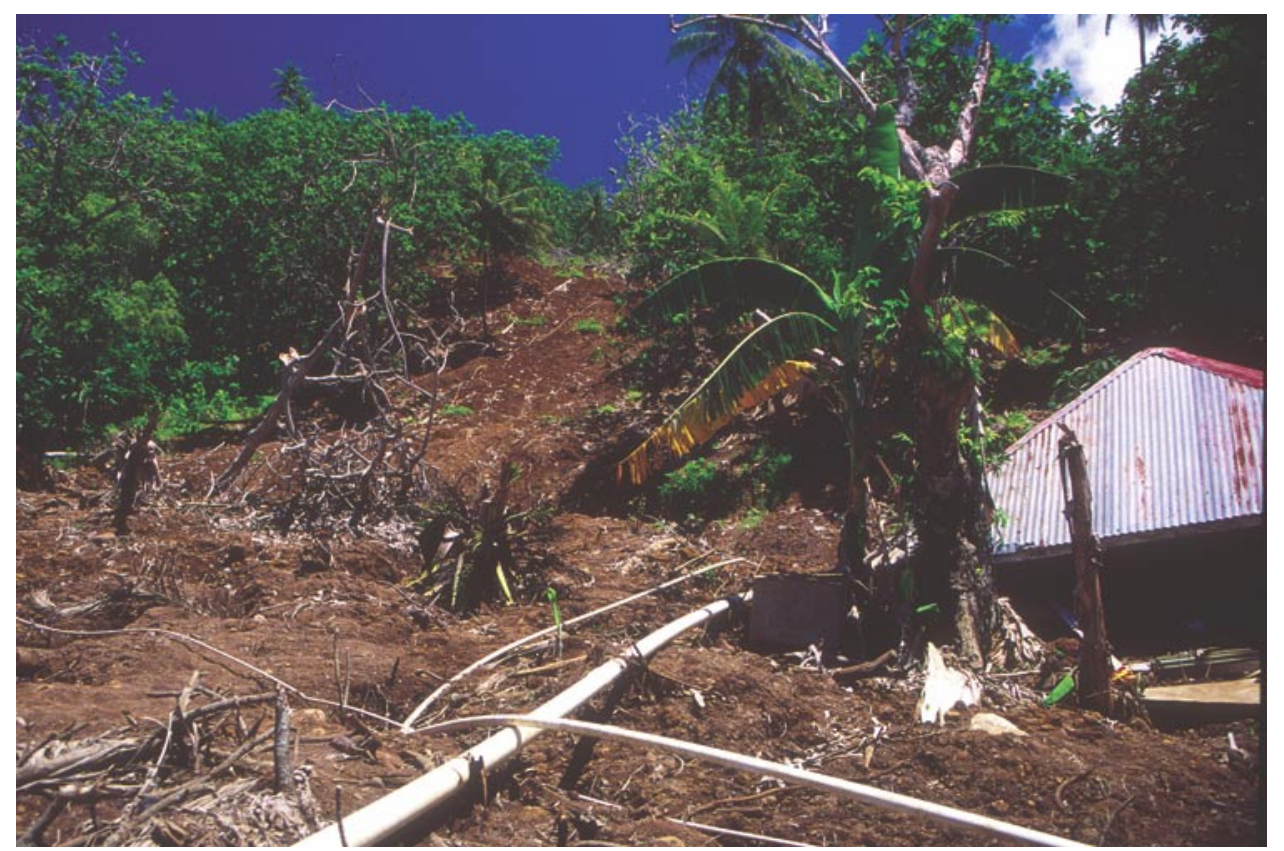

Figure 18. Lower portion of a slump/debris flow at the village of Sanuk on the island of Uman that destroyed 13 homes and a community center. 


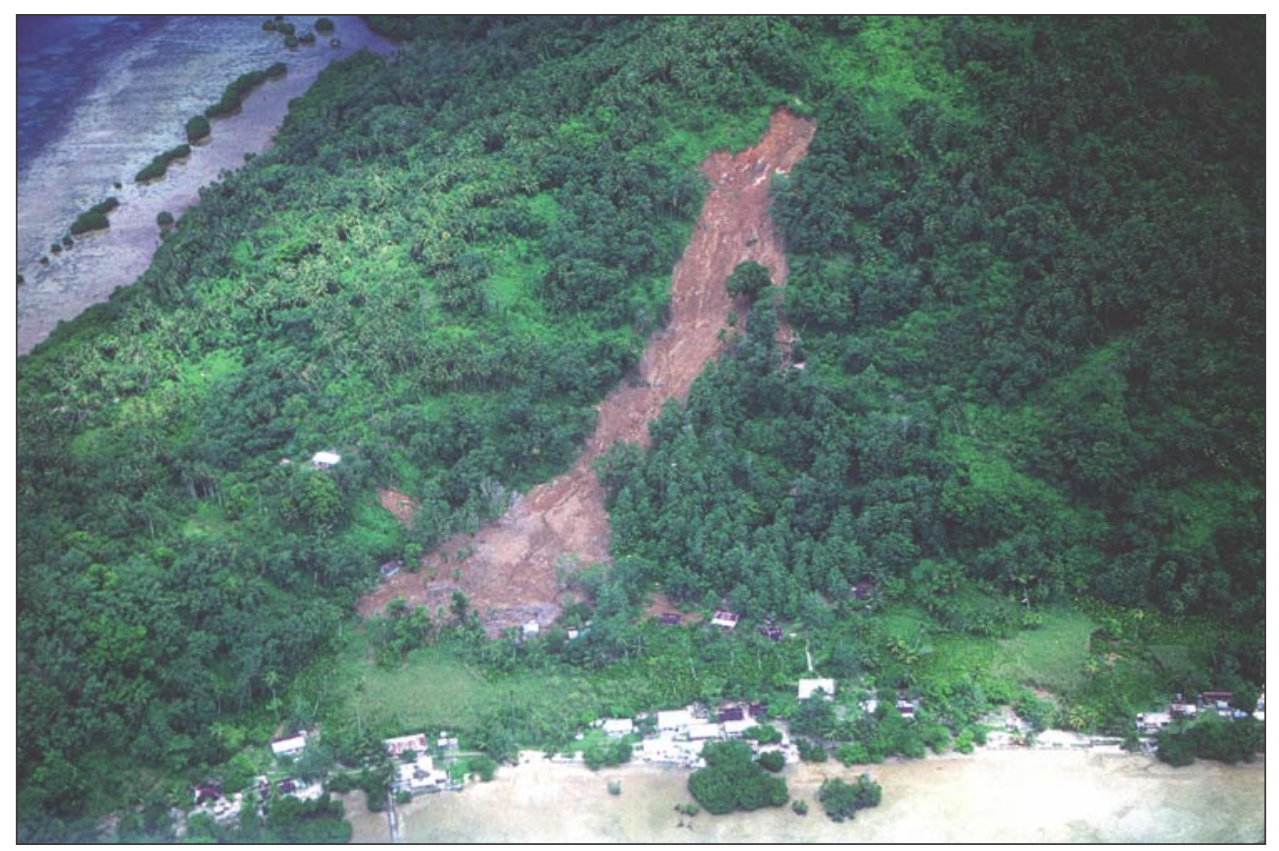

Figure 19. Aerial oblique view of slump/debris flow at the village of Penia on the island of Udot.

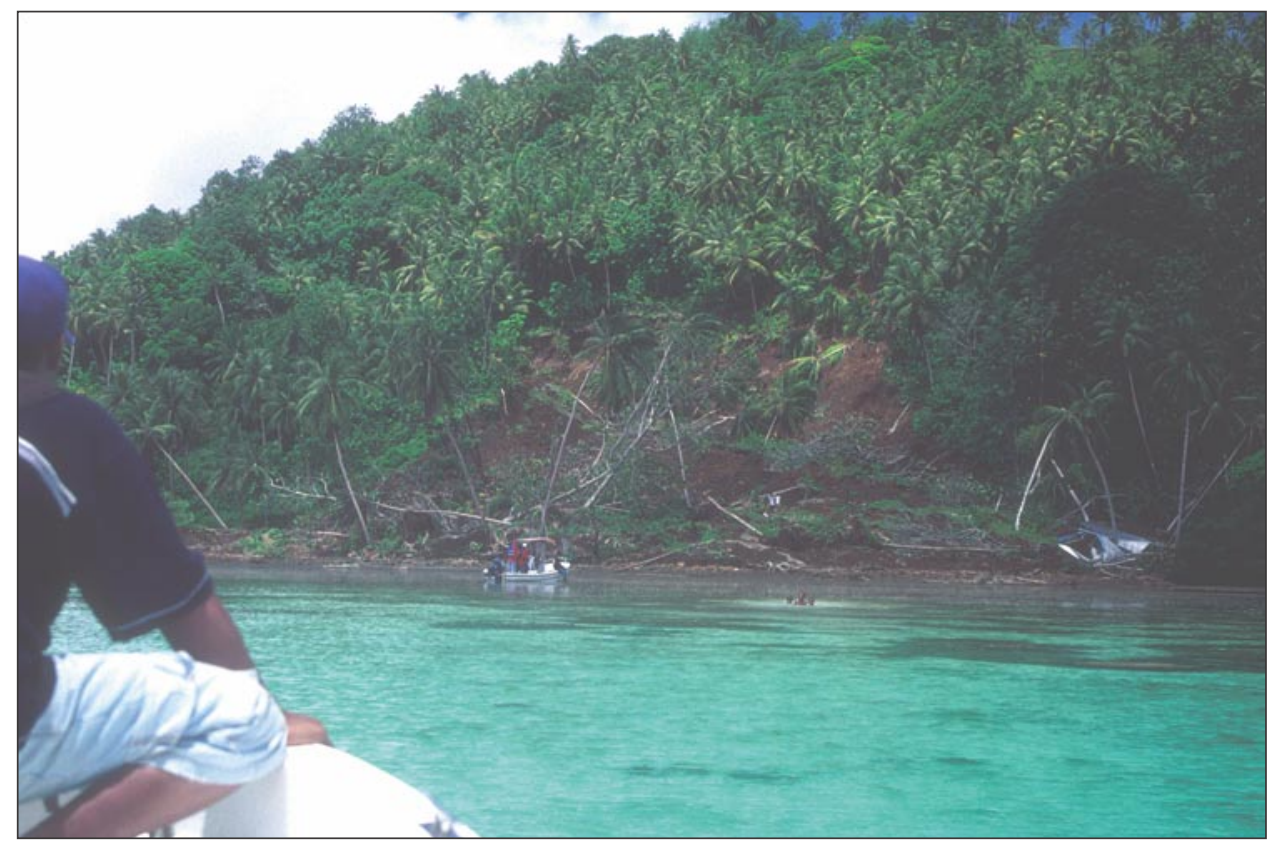

Figure 20. Faia slump/debris flow and incipient slumps that destroyed 15 homes and a dispensary on the island of Fanapanges. 


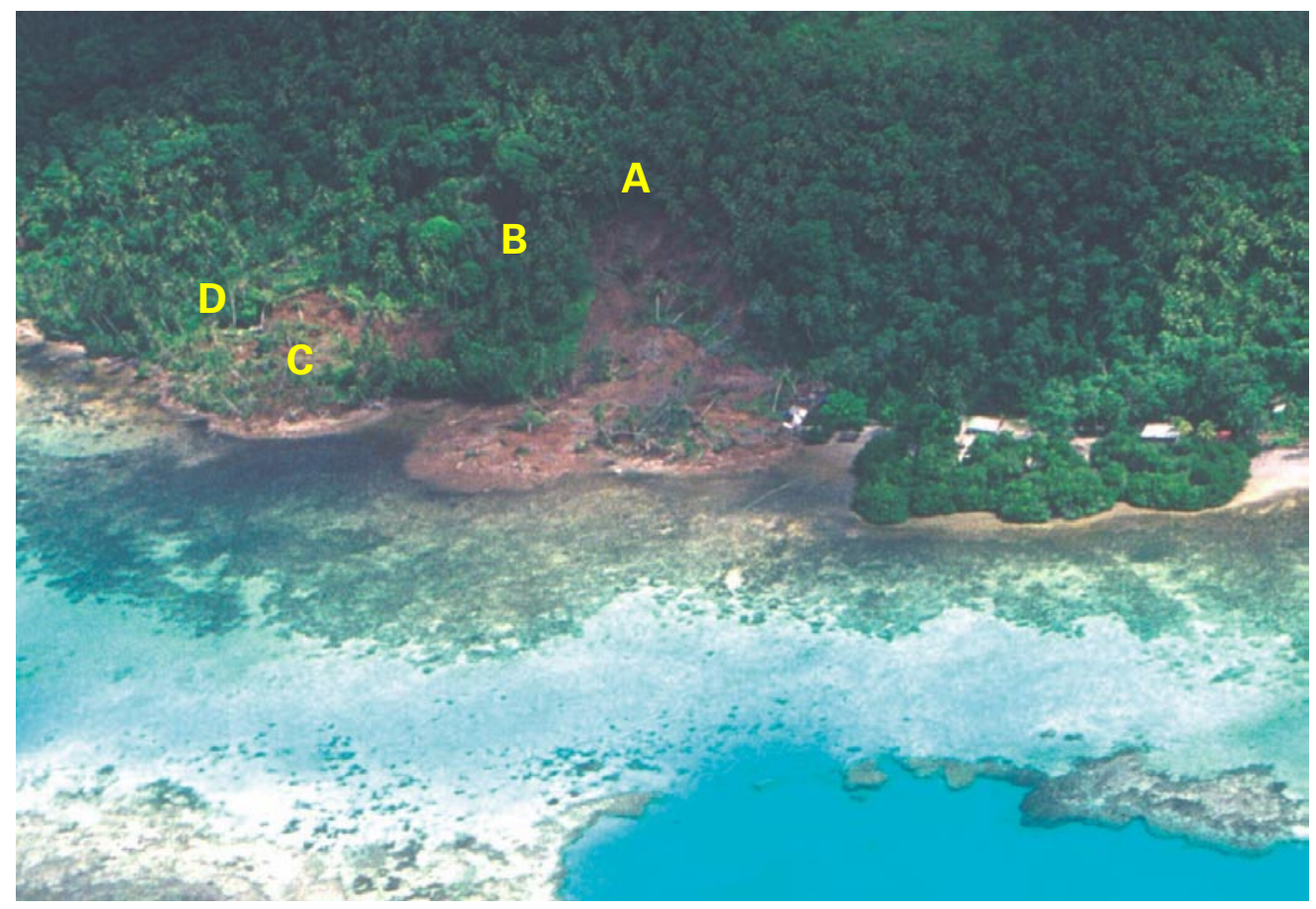

Figure 21. Aerial view of the Faia landslide and incipient slumps. Letters denote locations described in text.

\section{ASSESSMENT OF REMAINING AND FUTURE LANDSLIDE HAZARDS}

\section{Continuing Landslide Hazards}

Most of the landslides triggered by tropical storm Chata'an have undergone extensive failure and downslope movement, and the hazard at these landslide sites has decreased to fairly low levels. For those landslides where most of the landslide mass transformed into debris flows, the hazard to areas below the toe of the landslide now is relatively low because groundwater levels have decreased significantly from what they were when the failures were triggered, and because the movement of additional smaller failures from headscarp areas will be impeded by the presence of landslide material, which creates a rough, irregular surface within the flow path. Normal nontyphoon rainfall conditions are unlikely to generate additional landslides other than small failures from the oversteepened headscarps of the existing landslides. Small slumps and soil falls generated from these headscarps are unlikely to travel far from the base of the initial headscarp as their movement will be impeded by irregularities of the slide surface and previous landslide debris within the failure path. When we returned to the islands of Chuuk in September 2003, about 1 year after Chata'an, little additional movement had occurred at the landslide sites we visited. Most deposits were becoming heavily revegetated, and minor surface erosion had occurred on the landslide scars.

\section{Future Landslide Hazards}

The islands of Chuuk State eventually will be deluged by future severe tropical storms or typhoons that will, in turn, trigger new landslides. During times of fair weather and normal rainfall patterns, the slopes of the Chuuk islands probably will remain stable, because they are adapted to this level of rainfall. As discussed above, most of the landslide material from the Chata'an landslides already has been transported downslope by debris flows. New landslides from a future storm are likely to initiate from other hillslope areas; these include areas adjacent to the landslide scars from Chata'an, incipient landslides, or parts of hillslopes with geologic and hydrologic conditions similar to those where landslides have occurred in the past. We performed a slopestability analysis of the Chuuk islands affected by Chata'an to identify hillslope areas susceptible to landslides from a future large storm. We then developed a hazard map showing the likelihood of future landsliding on the slopes of these islands.

\section{Slope-Stability Analysis}

We used a geotechnical analysis method to evaluate the slope stability of each $10-\mathrm{m}$ by $10-\mathrm{m}$ area (grid cell) throughout the islands of Weno, Tonoas, Fefan, Etten, Uman, Udot, Eot, and Fanapanges affected by a future storm similar to Chata'an. Grid cells were defined by a 10-m digital elevation model (DEM) prepared by the USGS from 1:25,000scale topographic maps of the islands. The stability analysis compares the ratio of the resisting forces to the driving forces operating within each slope cell according to the equation: 


$$
F S=\frac{c^{\prime}}{\gamma t \sin \alpha}+\frac{\tan \phi^{\prime}}{\tan \alpha}-\frac{m \gamma_{w} \tan \phi^{\prime}}{\gamma \tan \alpha} \quad, \quad \text { Equation } 1
$$

where $F S$ is the static factor of safety, $c^{\prime}$ is the effective cohesion, $\phi^{\prime}$ is the effective friction angle, $\alpha$ is the slope angle, $\gamma$ is the material unit weight, $\gamma_{w}$ is the unit weight of water, $t$ is the slope-normal thickness of the slope element, and $m$ is the proportion of the element thickness that is saturated with ground water flowing parallel to the ground surface (Jibson and others, 2000; Harp and others, 2002). This method, commonly referred to as an infinite-slope analysis, approximates each slope cell as a rigid sliding block and assumes that the stability of each cell is independent of the cells surrounding it. High values of factor of safety reflect more stable slopes, whereas low values reflect relatively unstable slopes; values less than 1.0 indicate statically unstable slopes. Using equation 1, we calculated the FS for each slope element (grid cell); ranges of FS were then colored to produce a landslide-susceptibility map.

\section{Slope-Stability Analysis Variables}

To calculate $F S$ in a GIS-based analysis, we needed values for the variables listed in equation 1 for each $10-\mathrm{m}$ grid cell of the DEM. Insufficient information exists to determine all these variables for each cell, therefore some values were estimated. Ground- surface slope $(\alpha)$ was computed from the DEM grid cells using ArcGrid software (ESRI, 1998). An example of a slope map for the island of Tonoas is shown in figure 22 . The thickness of the potential sliding block $(t$ in equation 1) at each cell was estimated at a constant $3.5 \mathrm{~m}$, reflecting an average thickness of Chata'an-triggered landslides. For ground-water conditions during intense rainfall similar to tropical storm Chata'an, we assumed a fully saturated soil column with slope-parallel ground-water flow within all cells ( $m=1$ in equation 1$)$. Ground-water conditions undoubtedly varied from place to place and over time during Chata'an; nevertheless this assumption provides a relative "worst case" condition for computing slope stability.

Where no geotechnical data on strength properties and unit weights of geologic units are available, as in the case of Chuuk State, reasonable estimates can be made based on the type of materials present and the use of typical values associated with those types of materials (Harp and others, 2002; Jibson and others, 2000). Most steep slopes on the islands are mapped as "undivided volcanic rocks" described as "chiefly lava flows, basaltic and andesitic in composition" with lesser units of volcanic breccia (Stark and Hay, 1963). All of the large landslides that resulted in significant damage or loss of life were located within these materials. From our site observations, we noted the similarity between the landslide materials and those exposed in the landslide scarps. Because of this similarity throughout the islands that we visited and the landslide sites observed, we assigned a single value of unit weight and shear strength to all of the slope

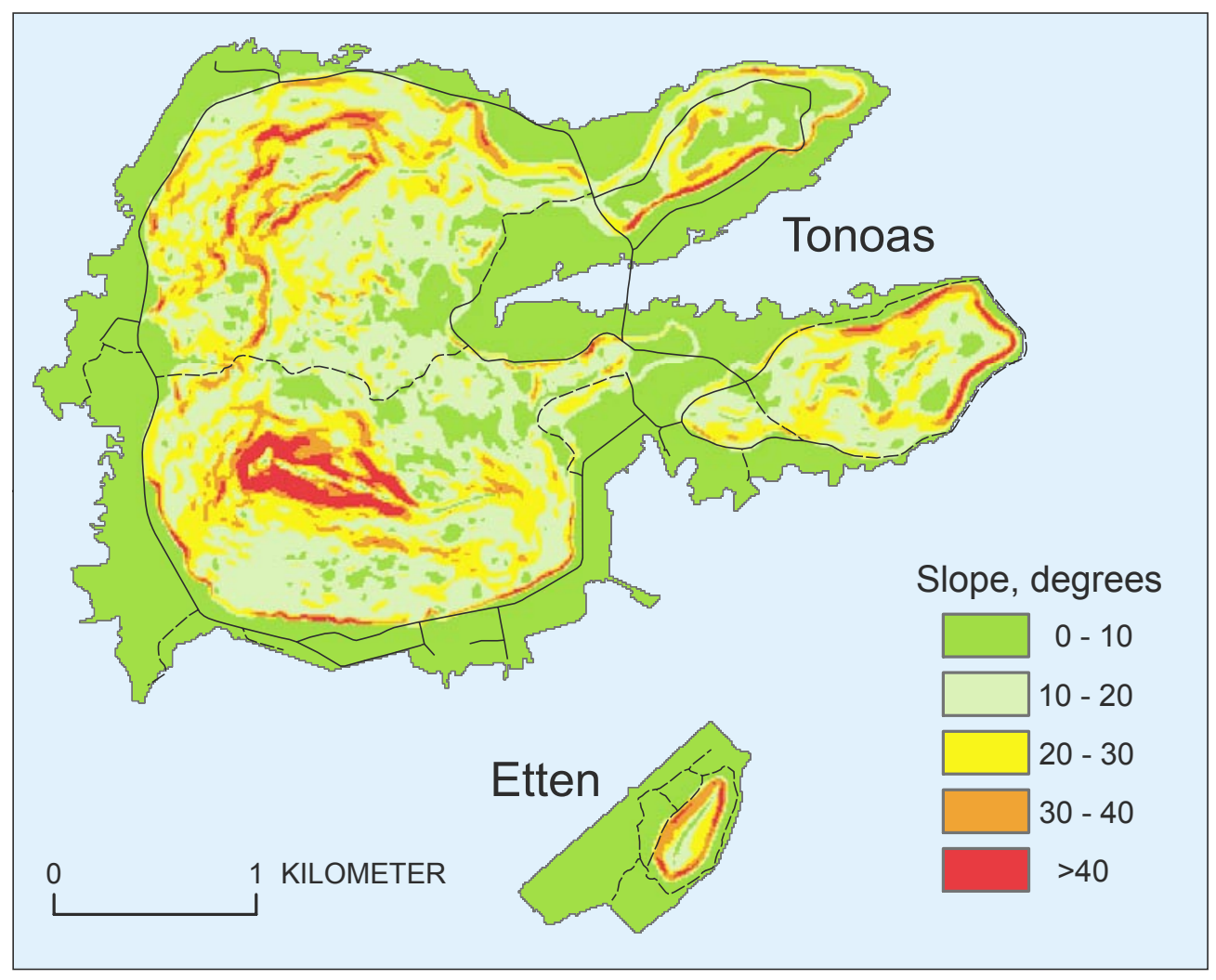

Figure 22. Slope map of the island of Tonoas prepared from a 10-m digital-elevation model (DEM). 
materials of the islands. We assigned the unit weight of soils $(\gamma$ in equation 1$)$ to be a constant $15.7 \mathrm{kN} / \mathrm{m}^{3}\left(100 \mathrm{lbs} / \mathrm{ft}^{3}\right)$. The shear strength of water-saturated soil or weathered rock consists of two components-effective cohesion (c') and effective angle of friction ( $\phi ')$. We calibrated spatially uniform values of these variables to capture the maximum amount of Chata'an landsliding in grid cells with the lowest computed stability while still using reasonable estimates of $\mathrm{c}$ and $\phi^{\prime}$ (see discussion in following section). This calibration process resulted in an estimated uniform c' of 38 kilopascals (kPa) $\left(800 \mathrm{lbs} / \mathrm{ft}^{2}\right)$ and $\phi$ ' of $24^{\circ}$. These values are reasonable for weak, weathered volcanic materials, and again provide a relative "worst case" condition. Thus, slope is the primary model variable that changed between 10 -m grid cells.

\section{Results: Factor-of-Safety (Susceptibility) Map}

Using equation 1, we computed the static factor of safety, $F S$, for each 10 -m grid cell of the affected Chuuk islands. The resulting slope-stability (factor-of-safety) map was then used to construct the debris-flow hazard map described in the next section. An example of the factor-of-safety map for the island of Tonoas is shown in figure 23. Factor-of-safety categories are portrayed on the map as different colors, ranging from magenta and red for the lowest values or least stable slopes to green for the highest values or most stable slopes. These colors indicate the general susceptibility of a given slope to landsliding in a storm similar to Chata'an. Overall, most of the debris flows initiated within slopes shown as magenta, red, or orange colors in figure 23, indicating a generally good agreement between the actual locations of landslide-source areas and those slopes predicted to be highly susceptible. There are, however, debris flows that initiated on slopes containing a significant number of cells of intermediate susceptibility. Notably, some of the larger debris flows on Tonoas, including those at Nechap, Kuchua, and Roro, initiated on slopes such as these. These debris flows began as complex deep-seated failures (greater than $10-\mathrm{m}$ thick and much larger than a $10-\mathrm{m}$ grid cell) with complex failure mechanisms (see discussions above). They are poorly represented by the slope-stability analysis described by equation 1 . In general, the smaller, thinner, and more numerous debris flows more closely approximate the assumptions of our stability analysis, for example, a simple sliding block of constant thickness. For these more common debris flows, our analysis performed well.

Theoretically, an $F S$ value of less than 1.0 means slope failure. To calibrate the hillslope strength in our slope stability analysis, we adjusted values of c' and $\phi$ ' so that many of the grid cells containing debris-flow sources produced by Chata'an had a $F S$ near 1. Because the mapped landslides shown in plate 1 contain both the source landslide and the debris flow track and deposit, we defined the debris-flow (landslide) source as the upslope quarter of each mapped landslide area. The value $F S=1.0$ portrayed on the map should not be considered as a precise threshold for slope failure for each specific site location because the data used in this

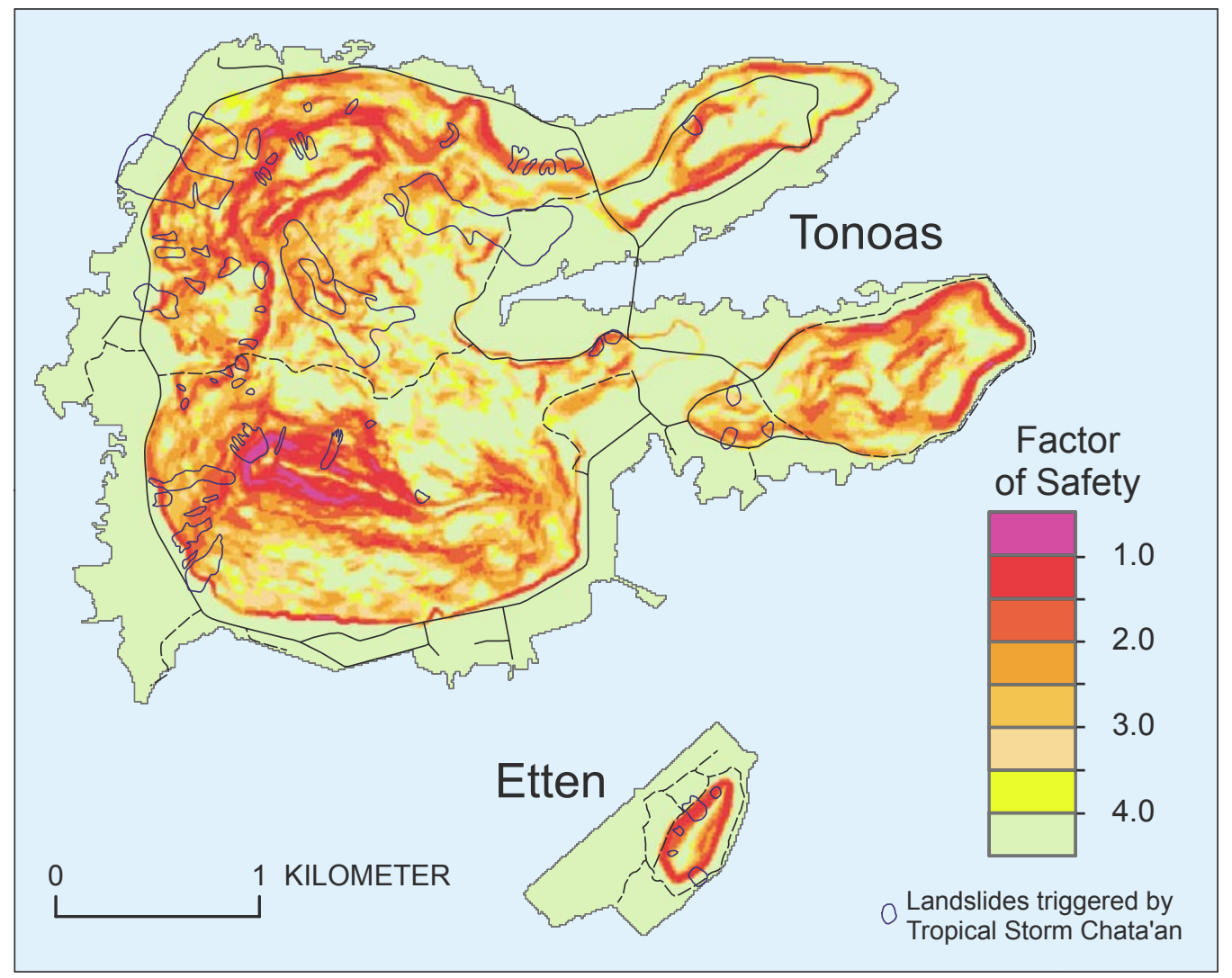

Figure 23. Factor-of-safety (susceptibility) map of the island of Tonoas using the slope-stability analysis described in text. 
relatively simple slope-stability analysis were generalized on a regional basis. Nevertheless, the clustering of mapped debrisflow sources within the lowest $F S$ categories indicates that this model is useful for establishing the relative susceptibility of various hillslopes. Comparing the computed $F S$ for each grid cell with the source locations of actual debris flows caused by Chata'an provides a tool to stratify or rank debris-flow source susceptibility.

The effectiveness of these factor-of-safety categories as predictors of landslide occurrence can be analyzed using the ratio of the number of 10-m landslide cells in each $F S$ category to the total number of $10-\mathrm{m}$ cells in each of the respective categories. This ratio for all the Chuuk islands analyzed is shown in figure 24 as a percentage. This percentage also expresses the spatial probability of a mapped landslide occurring in that FS category. The lowest FS categories have the highest spatial probabilities and are the best predictors of a landslide occurring within the respective categories. For example, if a parcel of land has an $F S$ value of between 0.5 and 1.0, figure 24 shows that there was about a 4.1-percent chance that a debris flow would have been triggered there by precipitation from tropical storm Chata'an. Similarly, areas having $F S$ values of between 1.0 and 1.5 had a 2.3 percent probability of sliding, and the pattern of decreasing percent probability continues with increasing $F S$ (fig. 24). With debrisflow source probability plotted versus $F S$ in figure 24, we were able to establish debris-flow hazard categories in terms of $F S$.

\section{Results: Debris-flow Hazard Map}

Using the results from our factor-of-safety analysis and our observations of debris-flow runout, we created a debris-flow hazard map for the Chuuk islands affected by Chata'an (pl. 2 ). This map portrays the hazard from two aspects of debris flows - their source landslides (usually on steeper slopes) and their runout paths (often on flat coastal lowlands). To portray the debris-flow source hazard, we divided the FS categories, shown in figure 24, from our slope-stability analysis into three groups. Areas with $F S=0.0-2.5$ contain landslide sources that make up 2 percent of the cells within this $F S$ group and are termed "high", $F S=2.5-4.0$ contain sources that make up 1 percent of the cells within this $F S$ group and are termed "moderate", and FS> 4.0 contain landslide sources that make up $\sim 0.1$ percent of the cells within this $F S$ group and are termed "low". These groups are assigned the colors red,

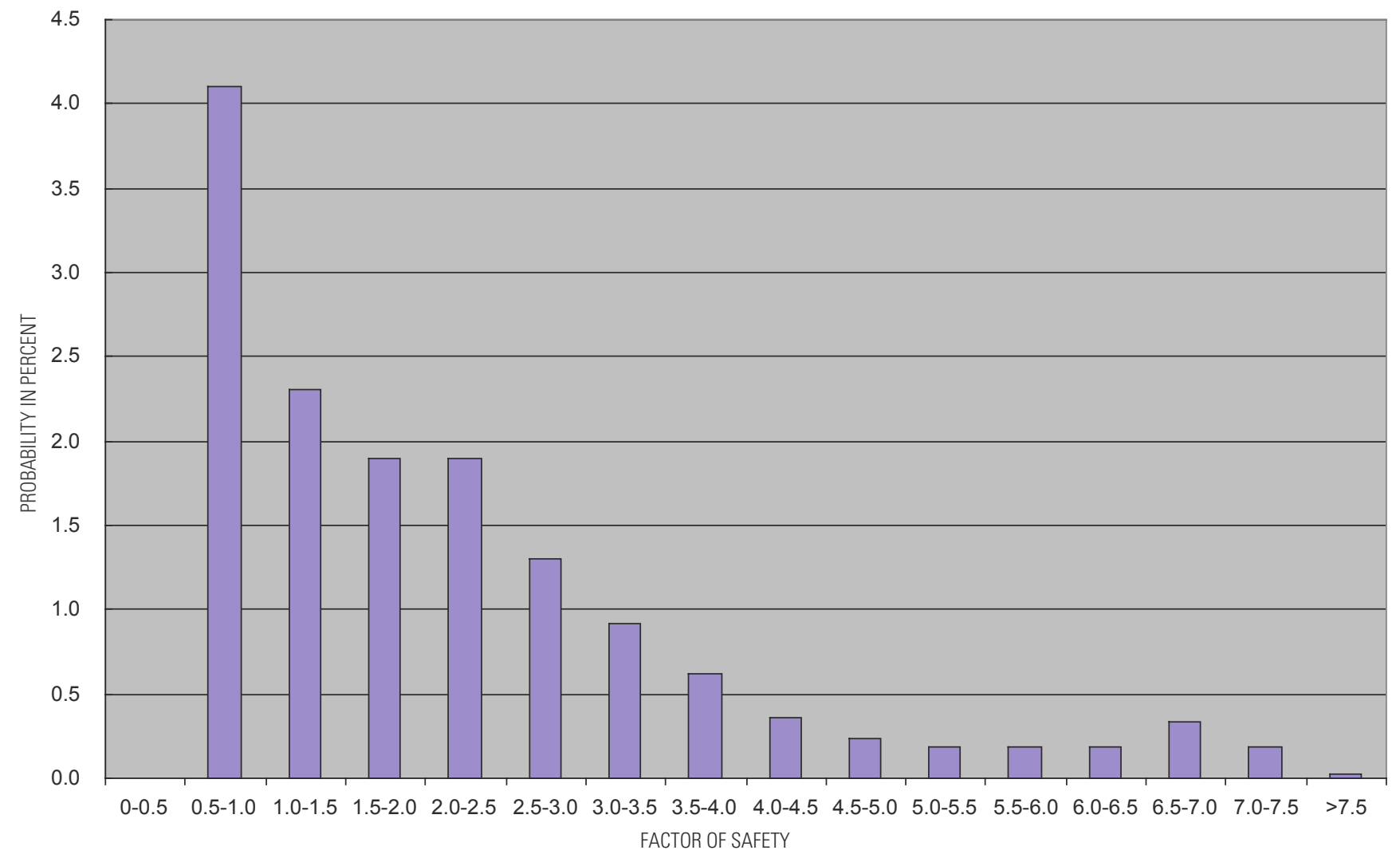

Figure 24. Histogram of debris-flow source probability versus factor-of-safety based on slope stability analysis of the islands of Weno, Tonoas, Fefan, Etten, Uman, Udot, Eot, and Fanapanges. Larger probabilities indicate an increased likelihood that a Chata'an-triggered landslide (debris-flow source) occurred on hillslopes with the corresponding factor-of-safety. 
yellow, and green, respectively, on plate 2. Figure 24 shows that $F S=0.5-1.0$ stands out noticeably from the rest of the data (highest probability), but the areal extent of this category is small. For this reason, we combined this FS category with the three adjacent bins, $F S=1.0-2.5$, that have similar values, to form the "high" hazard category. The limits of the "moderate" category are somewhat more arbitrary $(F S=2.5-4.0)$, although the probabilities in these two bins are significantly higher than in the rest of the bins $(F S>4.0)$. The bins with low probabilities form the "low" hazard category. In summary, areas of "high" hazard have a 2 percent probability, areas of "moderate" hazard have a 1 percent probability, and areas of "low" hazard have a 0.1 percent probability of producing slump/debris flows during rainfall conditions similar to those of tropical storm Chata'an in the eastern islands of Chuuk State.

The debris-flow hazard map shown in plate 2 illustrates that most of the debris flows triggered by Chata'an originated within "high" hazard areas. Only a few small landslides have source areas located in "moderate" or "low" hazard categories. This map, derived from the documented occurrence of debris flows from tropical storm Chata'an, predicts where "high," "moderate," and "low" debris-flow hazard is likely to occur from future extreme storms similar to Chata'an. For lesser rainfall conditions where total saturation of the soil may not occur, the susceptibility of the slopes to debris-flow initiation is lower. However, the relative susceptibility between hazard categories likely will be the same, that is, high hazard areas likely will contain the most landslides (debris-flow sources), although a storm smaller than Chata'an may produce fewer and smaller slides.

In addition to debris-flow hazard posed by the source areas, plate 2 also shows the expected runout areas of typical debris flows. An important question to most of the population living on the volcanic islands of Chuuk State is how far debris flows are likely to travel from the steep slopes out onto the coastal flats where most people live. To define this area of possible debris-flow inundation, we used the runout distances measured from debris flows triggered by Chata' an. These runout distances (discussed above) cover a broad range (fig. 5) but average $89 \mathrm{~m}$ beyond a significant break in topographic slope. Runout distances across the coastal flats commonly were less than this amount. Plate 2 shows potential runout areas onto the coastal flats (tan color) $100 \mathrm{~m}$ from the edge of steeper landslide-susceptible slopes. Areas beyond this 100-m line (farther from steep slopes) have a high probability of being unaffected by most debris flows; they are still at some risk from the relatively few, extremely large, long-runout debris flows. We chose $100 \mathrm{~m}$ as a relatively conservative (safer) limit; nevertheless, on most islands it identifies some relatively safe ground beyond the limit.

Our debris-flow hazard map was constructed using limited information and simplistic analytical methods; therefore, it has practical limitations. The assumptions inherent in our slope stability analysis are a significant simplification of natural hillslope conditions, where geologic and hydrologic conditions generally are quite variable and difficult to predict. Moreover, our analyses of stability and runout distances are based on observations from only one storm event, Chata'an. As discussed above, the locations of individual landslides from this event, shown on plate 1 , are approximate with varying accuracy. In future storms, not all of the high-hazard areas designated on plate 2 will be affected by landslides (Chata'an only affected a small percentage of the mapped high-hazard areas), and some slides are likely to occur outside these areas. Nevertheless, based on the Chata'an experience, high and moderate hazard areas identified on the map are more likely to be affected by future landslides and debris flows than the low hazard areas. Thus, the map can be used for planning purposes.

\section{Practical Use of the Debris-Flow Hazard Map}

Another tropical storm or typhoon, similar to Chata'an, likely will trigger abundant new debris flows on the volcanic islands. The debris-flow hazard map shown on plate 2 can be used to help reduce the impact from future storm-triggered debris flows. Because little public land exists in the Chuuk Islands, relocation of homes and other structures away from high hazard areas may be impractical. Nevertheless, important new or replacement structures, such as schools, community centers, and medical dispensaries, could be located away from moderate or high hazard areas and outside the 100-m debrisflow runout zone to reduce future risk from debris flows. Many people were killed during Chata'an by gathering in buildings in the direct path of debris flows. The hazard map identifies relatively low-risk safe zones (beyond the 100-m debris-flow runout limit) where residents could stay in public or private shelters during a future tropical storm similar to Chata'an. In the event of typhoon conditions and predicted heavy rainfall (similar to the almost 20 inches of rain in less than 24 hours that was recorded at the Weno airport during Chata'an), residents could travel to lower-risk shelters located beyond the runout areas identified by the debris-flow hazard map. To be effective, such shelter areas would need to be identified and well publicized prior to future storms. If such shelters had existed during Chata'an, undoubtedly some, but probably not all, of the debris-flow fatalities could have been avoided.

\section{SUMMARY AND CONCLUSIONS}

The intense rainfall accompanying tropical storm Chata'an in July 2002 triggered more than 250 landslides on the islands of Weno, Tonoas, Fefan, Uman, Etten, Udot, Fanapanges, and Siis in Chuuk State, Federated States of Micronesia. We visited these islands and many of the landslides a few weeks after the storm. The landslides ranged in volume from a few cubic meters to more than 1 million cubic meters; the majority mobilized into debris flows. The most damaging landslides were larger slumps near the coastal flats that transformed 
downslope and across the coastal flats causing 43 deaths and extensive property damage. The greatest area affected by landslides and the greatest damage done by landslides was on Tonoas. We mapped the landslides triggered by Chata'an (both source area and deposits) on 1:25,000-scale topographic maps to produce a landslide inventory map (pl. 1).

The continuing hazard posed by landslides triggered by Chata'an is low. However, future tropical storms or typhoons that produce intense rain, similar to Chata'an, likely will trigger new landslides and debris flows. To evaluate the hazard posed by future landslides to the islands of Chuuk State, we used GIS technology to perform a simple slope-stability analysis of each 10-m cell (from a DEM) of the islands listed above. This analysis computed a factor-of-safety, FS, (a measure of slope stability) for each 10-m grid cell using ground-surface slope angle and shear strength of geologic materials, assuming an average landslide thickness based on field observations, fully saturated slope conditions, and slopeparallel ground-water flow. We calibrated the analysis by varying uniform slope strength until the majority of observed source landslides triggered by Chata' an were located in cells with low FS. We then computed the spatial probabilities of landslides occurring during Chata' an for each range of FS. Using this information, we constructed a debris-flow hazard map (pl. 2). This map portrays the expected relative landslide hazard (high, moderate, and low) on steep slopes during a future storm similar to Chata'an. It also portrays areas that may be inundated by large debris flows during such a storm, as well as areas that are relatively safe from future debris flows.

The inventory map of landslides and debris flows triggered by tropical storm Chata'an (pl. 1) serves as a record to compare with any future occurrence of landslides in the islands of Chuuk State. The debris-flow hazard map (pl. 2) can be used to select locations that are relatively safe from future landslides and debris flows. This map may aid the siting of new public facilities, such as schools, community centers, and medical dispensaries. It also may be used to help select and designate evacuation areas where residents can gather in relative safety when future tropical storms and typhoons trigger landslides in these islands.

\section{ACKNOWLEDGMENTS}

The authors express their appreciation to the Federal Emergency Management Agency (FEMA) for funding the reconnaissance and analysis presented here and to the U.S. Army Corps of Engineers (USACE) for providing logistical support and direction as a subtasking agency. Individual thanks go to Nick Russo, FEMA Federal Coordinating Officer on Chuuk, to Ken Suiso, USACE, for help with transportation logistics and the reconnaissance flight, to Ray Kong and Ed Flint for assistance in the fieldwork and its logistics, to Rusty Witwer and Tom Atkin of the U. S. Forest Service for assistance with follow up investigations in 2003, to Johnson Elimo of the U. S. National Weather Service for providing rainfall data, and to Dianne Brien of the USGS for help with digital maps. We especially thank Marcelino Elias and Innocente Penno for their guide services and assistance in contacting local residents and gathering information.

\section{REFERENCES CITED}

Ellen, S.D., Iverson, R.M., and Pierson, T.C., 1991, Map showing the distributions of debris flows during the New Year's Eve storm of 1987-1988 in southeastern Oahu, Hawaii: U.S. Geological Survey Open-File Report 91129, scale 1:20,000.

ESRI, 1998, Using ARC GRID with ARC/INFO, v. 1, Environmental Systems Research Institute, Redlands, California.

Hamlin, S.N., and Takasaki, K.J., 1984-85, Water-quality reconnaissance of ground water in the inhabited outer atoll islands of Chuuk State, Federated States of Micronesia: U.S. Geological Survey Water-Resources Investigations Report 96-4180, 77 p.

Harp, E.L., Held, M.D., Castañeda, M.R., McKenna, J.P., and Jibson, R.W., 2002, Landslide hazard map of Tegucigalpa, Honduras: U.S. Geological Survey Open-File Report 02219, 9 p., 2 pl.

Harp, E.L., and Savage, W.Z., 1997, Landslides triggered by the April 1997, tropical storms in Pohnpei, Federated States of Micronesia: U.S. Geological Survey Open-File Report 97-696, 10 p., 1 pl.

Jibson R.W., Harp, E.L., and Michael, J.A., 2000, A method for producing digital probabilistic seismic landslide hazard maps: Engineering Geology, p. 271-289.

Jibson, R.W., 1989, Debris flows in southern Puerto Rico, in Schultz, A.P., and Jibson, R.W. (eds.), Landslide processes of the eastern United States and Puerto Rico: Geological Society of America Special Paper 236, p. 29-55.

Peterson, D.M., Ellen, S.D., and Knifong, D.L., 1993, Distribution of past debris flows and other rapid slope movements from natural hillslopes in the Honolulu District of Oahu, Hawaii: U.S. Geological Survey OpenFile Report 93-514, $32 \mathrm{p}$.

Stark, J.T., and Hay, R.L., 1963, Geology and petrography of volcanic rocks of the Truk Islands, East Caroline Islands: U.S. Geological Survey Professional Paper 409, 41 p., 2 pl.

Varnes, D.J., 1978, Slope movement types and processes, in Landslides: Analysis and Control, Special Report 176, Schuster, R.L. and Krizek, R.J., eds., TRB, National Research Council, Washington, D.C., p. 11-33. 